\title{
Summer activity patterns for a moss and lichen in the maritime Antarctic with respect to altitude
}

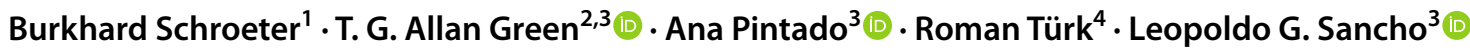

Received: 22 June 2020 / Revised: 31 August 2021 / Accepted: 6 September 2021 / Published online: 5 October 2021

(c) The Author(s) 2021

\begin{abstract}
There is considerable scientific interest as to how terrestrial biodiversity in Antarctica might respond, or be expected to respond, to climate change. The two species of vascular plant confined to the Antarctic Peninsula have shown clear gains in density and range extension. However, little information exists for the dominant components of the flora, lichens and bryophytes. One approach has been to look at change in biodiversity using altitude as a proxy for temperature change and previous results for Livingston Island suggested that temperature was the controlling factor. We have extended this study at the same site by using chlorophyll fluorometers to monitor activity and microclimate of the lichen, Usnea aurantiaco-atra, and the moss, Hymenoloma crispulum. We confirmed the same lapse rate in temperature but show that changes in water relations with altitude is probably the main driver. There were differences in water source with $U$. aurantiaco-atra benefitting from water droplet harvesting and the species performed substantially better at the summit. In contrast, activity duration, chlorophyll fluorescence and photosynthetic modelling all show desiccation to have a large negative impact on the species at the lowest site. We conclude that water relations are the main drivers of biodiversity change along the altitudinal gradient with nutrients, not measured here, as another possible contributor.
\end{abstract}

Keywords Chlorophyll fluorescence $\cdot$ Microclimate $\cdot$ Photosynthesis $\cdot$ Poikilohydric $\cdot$ PSII activity $\cdot$ Altitudinal gradient

Dedication This paper is dedicated to Professor Ludger

Kappen to recognise not just his immense contribution to our understanding of Antarctic terrestrial vegetation but, also, that he introduced most of the authors to Antarctic research. He has left a massive legacy which underpins much of present understanding of Antarctic terrestrial systems.

Leopoldo G. Sancho

sancholg@ucm.es

T. G. Allan Green

greentga@waikato.ac.nz

1 Leibniz Institute for Science and Mathematics Education (IPN), 24098 Kiel, Germany

2 Biological Sciences, University of Waikato, Private Bag 3105, Hamilton, New Zealand

3 Section of Botany, Facultad de Farmacia, Universidad Complutense, 28040 Madrid, Spain

4 Department of Organismic Biology, University of Salzburg, Salzburg, Austria

\section{Introduction}

SCAR (Scientific Committee on Antarctic Research, www. scar.org) places threats to biodiversity due to climate change at the core of their research themes with Antarctica being predicted to warm by around $3.4^{\circ} \mathrm{C}$ by the end of the $21 \mathrm{st}$ Century. In their main research programme, State of the Antarctic Ecosystem, the most important topic is "Spatial Ecology" with one research question being: What are the systematic and environmental geographic features of Antarctic biodiversity, and what mechanisms underpin the current distribution and abundance of biodiversity? Over recent decades our knowledge of the Antarctic terrestrial vegetation has improved considerably (Green et al. 2007) together with an interest as to how biodiversity might be responding, or be expected to respond, to climate change. One technique has been to impose increased temperature regimes on vegetation and to follow any consequential changes. The normal technique to achieve passive warming has been the use of open top chambers which typically produce around $2 \mathrm{~K}$ warming (Bokhorst et al. 2011). However, recent reviews of the results from such research suggest that this approach 
had generally been unsuccessful because environmental factors other than temperature are also changed, particularly, changes in snow cover and duration (Casanova-Katny et al. 2019; Convey and Peck 2019). An alternative approach is to use change in vegetation structure and performance along an altitudinal gradient as a proxy for continental temperature change because of the lapse rate in temperature that is typically around $1{ }^{\circ} \mathrm{C}$ per $100 \mathrm{~m}$ gain in altitude (Breshears et al. 2008; Körner 2021). A good example of such an approach is the study by Pintado et al. (2001) in which the change in lichen diversity on Mt. Reina Sofia (275 m) on Livingston Island (South Shetland Islands) was shown to correlate with a $2{ }^{\circ} \mathrm{C}$ decline in mean temperature. Pintado et al. (2001) based their conclusions on records of microclimate temperature made within the lichen vegetation.

In the present study we extend this analysis on Mt. Reina Sofia by including new temperature data together with information on lichen and moss activity obtained from in situ chlorophyll fluorescence measurements. Chlorophyll fluorescence techniques allow the activity periods of the vegetation components to be determined together with the concurrent environmental conditions. It is known from previous studies that the level of linkage between environmental conditions when active and ambient conditions depends on the proportion of the time that the plants are active. Lower activity results in uncoupling of the active organisms from the incident conditions (Schlensog et al. 2013).

It is first worthwhile to consider from the recent research literature what responses in terrestrial biodiversity might be expected with change in temperature in Antarctica. At the continental level it is reported that the major terrestrial vegetation types, lichens, mosses and liverworts, all show a highly significant link with mean annual temperature with a strong decline in biodiversity with fall in mean temperature as latitude increases (Peat et al. 2007; Green et al. 2011b) However, this apparently straight forward correlation hides complexity and our inability, at present, to evaluate the importance of particular (and co-acting) environmental factors.

At the continental level, the correlations of biodiversity with mean annual temperature show a linear decline to zero occurrence at around $72^{\circ}$ latitude (the extreme north of the Ross Sea region). However, this is obviously not correct because liverworts are reported to $77^{\circ} \mathrm{S}$ Latitude (Seppelt et al. 2010) and lichens and mosses reach $86^{\circ} \mathrm{S}$ (Green et al. 2011c; Colesie et al. 2014b). As a consequence, it is suggested that two major zones exist which reflect ambient water relations, one being the Macroenvironmental Zone, north of latitude $72^{\circ} \mathrm{S}$ in which biodiversity shows a strong link to the ambient environmental conditions. In the other, the Microenvironmental Zone south of latitude $72^{\circ} \mathrm{S}$, incident precipitation is not enough to maintain the vegetation and distribution is determined by landscape i.e. by the occurrence of melt water (Schwarz et al. 1992; Seppelt et al. 2010). In the latter zone, therefore, vegetative cover is not related to incident macroenvironmental conditions. The boundary at $72^{\circ} \mathrm{S}$ is a good example of a tipping point in Antarctic vegetation and is predicted to move south at the approximate rate of around 1 degree latitude per $1{ }^{\circ} \mathrm{C}$ change in mean annual temperature. Furthermore, biodiversity studies suggest that although actual occurrence is abiotically controlled (i.e. where water occurs) the actual species present are biotically controlled on the basis of first in best served, i.e. a stochastic colonisation followed by exclusion due to space limitation. The latter suggestion is supported by the very low similarities between biodiversity at different sites (Colesie et al. 2014b). A further complication in this region, Ross Sea, is the strong likelihood that a large component of the vegetation at the most southerly sites (Beardmore Glacier, $84^{\circ} \mathrm{S}$ ) is composed of relic species that have survived since the last collapse of the West Antarctic Ice Sheet and are found elsewhere only in the north of the Antarctic Peninsula (Green et al. 2011c). Similar discontinuities are reported for the collembola species (Stevens and Hogg 2003) and this means that correlations with ambient macroclimate have little value within the Ross Sea region.

Native vascular plants are a minor component in the vegetation of continental Antarctica and are confined to the Antarctic Peninsula. Only two species occur and they both show a strong linkage in distribution and cover to temperature (Torres-Mellado et al. 2011). The dominant vegetation types, lichens and bryophytes, are poikilohydric and have thallus water contents that equilibrate with the environment meaning that they are often dry and dormant during the Austral summer season (Green et al. 2011a). It would be expected, therefore, that water availability might have an important influence on occurrence and performance of these species and this is supported by the distributions in Microenvironmental Zone commented on above. This is particularly clear for bryophytes which are almost completely confined to areas of consistent water availability, such as flushes related to snow melt, and where lichens are effectively excluded by physiological limitations due to depressed photosynthetic rate at high thallus water contents (Green and Lange 1995). Water flows due to snow melt are relatively stable once they have started in the summer and this leads to high levels of activity, often continuous for long periods (Pannewitz et al. 2003a; Schroeter et al. 2017). However, small changes in flow directions due to sediment deposition, excessive erosion at high flow rates, or simply changes in snow fall or wind aided snowbank formation, will have a large effect on bryophyte activity and distribution (Brabyn et al. 2006; Nielsen et al. 2012; Levy et al. 2014; Robinson et al. 2018). Such changes are indirectly linked to temperature.

Lichens, in particular, seem to be excellent indicators of climate change in Antarctica. In addition to a strong, positive 
relationship between diversity and cover with temperature across Antarctica, they also show alterations in growth rates that are highly sensitive to even small changes $\left(<1{ }^{\circ} \mathrm{C}\right)$ in mean ambient temperatures (Sancho et al. 2017). One must be cautious in extending this statement to all lichens and to just to consider changes in temperature. Sancho et al. (2019) showed that responses were very species-specific and that the effect on growth rate of a $0.5^{\circ} \mathrm{C}$ increase in summer temperature ranged from $+49 \%$, in Usnea antarctica, through $+11 \%$, in Acarospora macrocyclos, to no response, in Buellia latemarginata, and a decline, $-15 \%$, in Caloplaca sublobulata. Warmer temperatures might be expected to lead to greater carbon gain due to higher net photosynthesis because lichens in Antarctica are active at temperatures below the optimum for photosynthesis which is typically above $10{ }^{\circ} \mathrm{C}$ in both field and laboratory studies (Schroeter et al. 1995; Pannewitz et al. 2006; Green et al. 2011b). However, one should not disregard other possible controls on growth. Carbon gain depends not just on absolute photosynthetic rates but also on the balance between activity in the light, with carbon fixation, and in the dark, carbon loss by respiration. Warmer winter temperatures, when water is available under low light conditions, could result in enhanced carbon loss. A good example of this effect is found in the long-term monitoring of Usnea aurantiacoatra on Livingston Island (Schroeter 1997). From 1992 to 1994, there was a decline from high carbon gain $(120 \mathrm{mg}$ $\left.\mathrm{CO}_{2} \mathrm{gdw}^{-1}\right)$ to a small carbon loss $\left(0.64 \mathrm{mg} \mathrm{CO}_{2} \mathrm{gdw}^{-1}\right)$ which was driven by a $24 \%$ drop in activity in the light coupled with a $45 \%$ increase in activity in the dark concurrent with an increase in mean thallus temperature when active $\left(-0.7{ }^{\circ} \mathrm{C}\right.$ to $\left.+0.9^{\circ} \mathrm{C}\right)$. Large changes in maximal net photosynthesis from year to year, and between locations, have been shown for the lichen Xanthoria mawsonii (=Xanthomendoza borealis) (Pannewitz et al. 2006). In addition, an absolute increase in carbon gain is not directly linked to growth because changes in carbon allocation can occur, for example, from a stress tolerating to a growth targeted strategy with increase in temperature (Colesie et al. 2014a).

Studies based on gradients, such as temperature, assume that changes are gradual over both time and space. However, there is growing evidence that short-term catastrophic events can have major effects on vegetation. The growth studies by Sancho et al. $(2017,2019)$ at Livingston Island showed that some species were extremely sensitive to extended periods of snow cover leading to loss of complete thalli. Such snowkill is known from the northern hemisphere (Lévesque and Svoboda 1999). Snow accumulation is also reported to cause poor performance, even death, of lichens in open top chambers which, at some sites, can capture snow leading to extended periods of snow cover at sites where it would normally not occur (Bokhorst et al. 2013). Snowkill is probably an under-reported event in Antarctica but is suggested to drive lichen distribution by thallus removal and release of rock surfaces for colonisation as far south as the Dry Valleys, $78^{\circ} \mathrm{S}$, (Green et al. 2012) and explain lichen communities of different ages in Ryder Bay, Adelaide Island (Golledge et al. 2010). It is even possible that a decline in the upper altitude boundary for the higher plants, Deschampsia antarctica and Colobanthus quitensis, at Signy Island is also explained by recent increases in snow fall (Cannone et al. 2016). The occurrence of such events will weaken any links in biodiversity to global climate change.

Using the original lichen distribution data from Pintado et al. (2001) we aim to use not only a new set of environmental data from an altitudinal gradient on Mt. Reina Sofia but also information from chlorophyll fluorescence measurements that reveal microclimatic conditions when the species are active to answer the following aims:

1. To confirm the original lapse rate in temperature obtained by Pintado et al. (2001) and to see if absolute values have changed.

2. To determine the level of activity of the fruticose lichen U. aurantiaco-atra (Jacq.) Bory and the moss Hymenoloma crispulum (Hedw.) Ochyra (= Dicranoweisia crispula (Hedw.)) at sites along the altitudinal gradient.

3. To analyse the activity patterns and modelled photosynthesis of the moss and lichen to determine the key environmental drivers and to see if these differ with altitude and species.

4. In summary, to decide if temperature is confirmed as the main driver of diversity change or whether some other factors e.g. changes in water relations, are relevant, possibly even dominant.

\section{Materials and methods}

\section{Location and species}

The research site was located in the vicinity of the Spanish Juan Carlos I Station at South Bay, Livingston Island, South Shetland Islands $\left(62^{\circ} 39^{\prime} 46^{\prime \prime} \mathrm{S}, 60^{\circ} 23^{\prime} 20^{\prime \prime} \mathrm{W}\right.$; Fig. 1). Livingston Island lies within the Macroenvironmental Zone (Green et al. 2011c) with biodiversity driven by ambient environmental conditions. South Bay is known to be a rich area for vegetation and 187 species of lichens and 59 bryophytes have been reported from the area (Sancho et al. 1999; Søchting et al. 2004). In addition, both Antarctic phanerogams (Deschampsia antarctica Desv. and Colobanthus quitensis (Kunth) Bartl.) are abundant (Vera 2011). At sites with a regular water supply, a lush bryophyte vegetation forms extensive cushions ('tall moss cushion subformation' of 'Antarctic nonvascular cryptogam tundra formation'). Dry habitats on rock and scree are mainly dominated by fruticose 


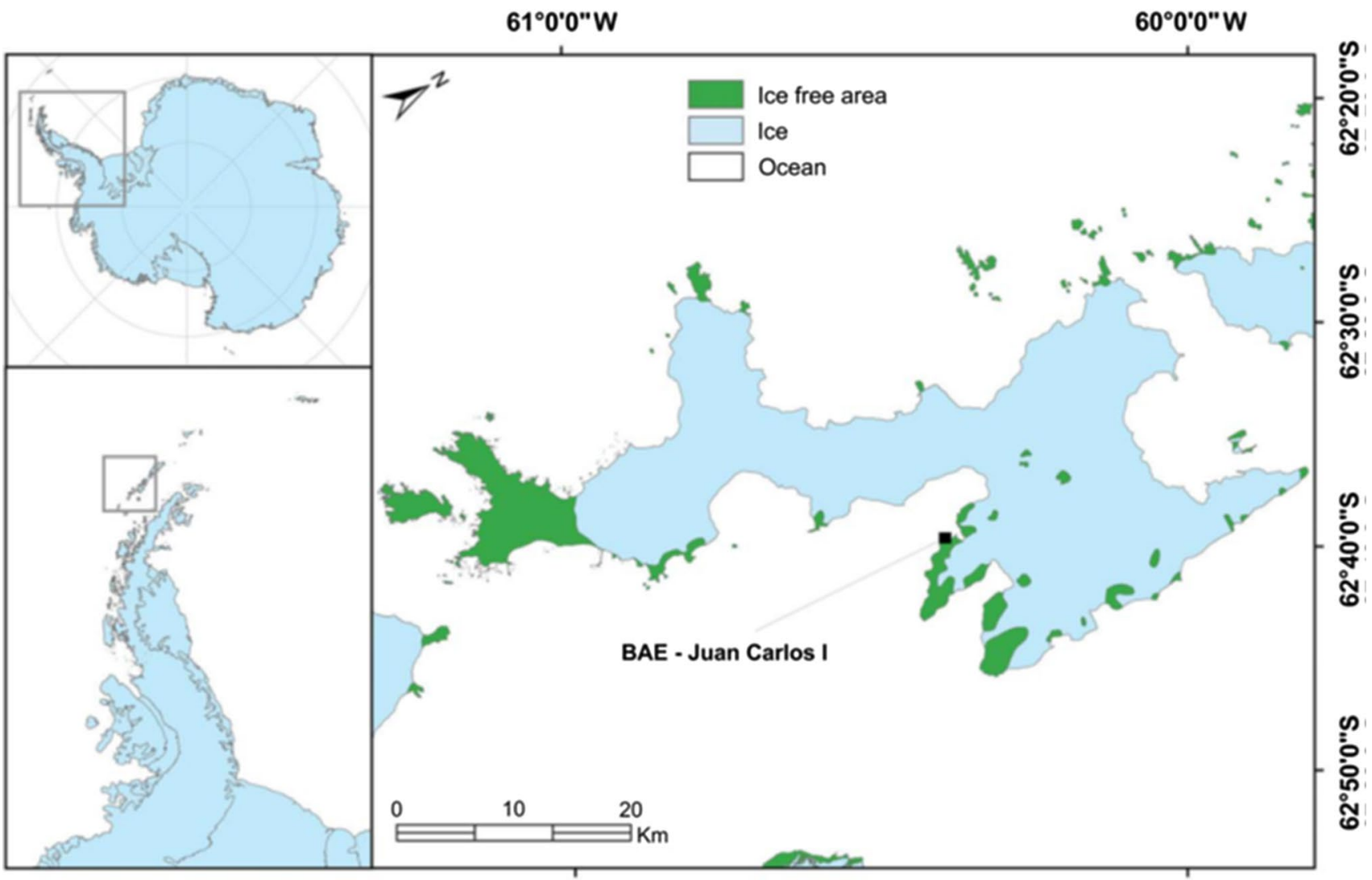

Fig. 1 Map showing the location of the research site adjacent to the Juan Carlos I Base $\left(62^{\circ} 39^{\prime} 47^{\prime \prime} \mathrm{S} 60^{\circ} 23^{\prime} 17^{\prime \prime} \mathrm{W}\right)$ on Livingston Island in the South Shetland Islands to the west of the Antarctic Peninsula.
Darker areas on islands indicate ice-free land, lighter areas indicate permanent ice/snow cover and foliose lichens (Usnea spp. and Umbilicaria spp.), occasionally interspersed with mosses of the short cushion form and can be assigned to the 'fruticose and foliose lichen subformation' of the 'Antarctic non-vascular cryptogam tundra formation' (Smith 1996).

Three measurement sites were selected (Fig. 2a), Top site, at the summit of Mt. Reina Sofia, $275 \mathrm{~m}$ altitude, a small summit ridge which is flat and fully exposed, composed of small rocks covered with lichens (Fig. 3a); Middle site, on a rocky ridge on the west slope of Mt. Reina Sofia at $105 \mathrm{~m}$ altitude, slight slope to the north-east, fully exposed with a similar surface structure to the summit site (Fig. 3c); and Bottom site, on a large rock in the vicinity of the Base buildings at $9 \mathrm{~m}$ altitude, rock surface, almost vertical, NNE exposure $\left(30^{\circ}\right)$ (Fig. 3e). The measurement sites were all exposed rock surfaces which were not in a meltwater channel so that the cryptogamic vegetation (mainly fruticose and foliose lichens) was hydrated by precipitation (snow, rainfall or fog). At each site two samples were monitored, one of the common fruticose lichen $U$. aurantiaco-atra and one of the moss $H$. crispulum (Fig. 3). The moss and lichen samples were close to each other, less than a metre apart and even directly adjacent at the Top site (Fig. 3b). All three sites are within the 'fruticose and foliose lichen subformation'.

\section{Microclimate}

Microclimatic conditions, i.e. air and thallus temperatures, light and relative air humidity, were recorded over the same period as the chlorophyll fluorescence and at the individual sample sites. The microclimatic data were logged at $30 \mathrm{~min}$ intervals using Squirrel data loggers (Grant, UK). Thallus and air temperature were measured with microthermistors (diameter $0.6 \mathrm{~mm}$ ) and thermocouple probes with those used for air temperature being shielded from direct radiation. The microthermistors were fixed to the rock using terostat and, for the moss inserted into the cushion, and for the lichen either inserted into one of the thicker branches or pressed against one of the thallus branches. They were 
Fig. 2 a Mount Reina Sofia and Juan Carlos I Base showing the location of the three sites, Top, Middle and Bottom. b Mount Reina Sofia with cloud cap

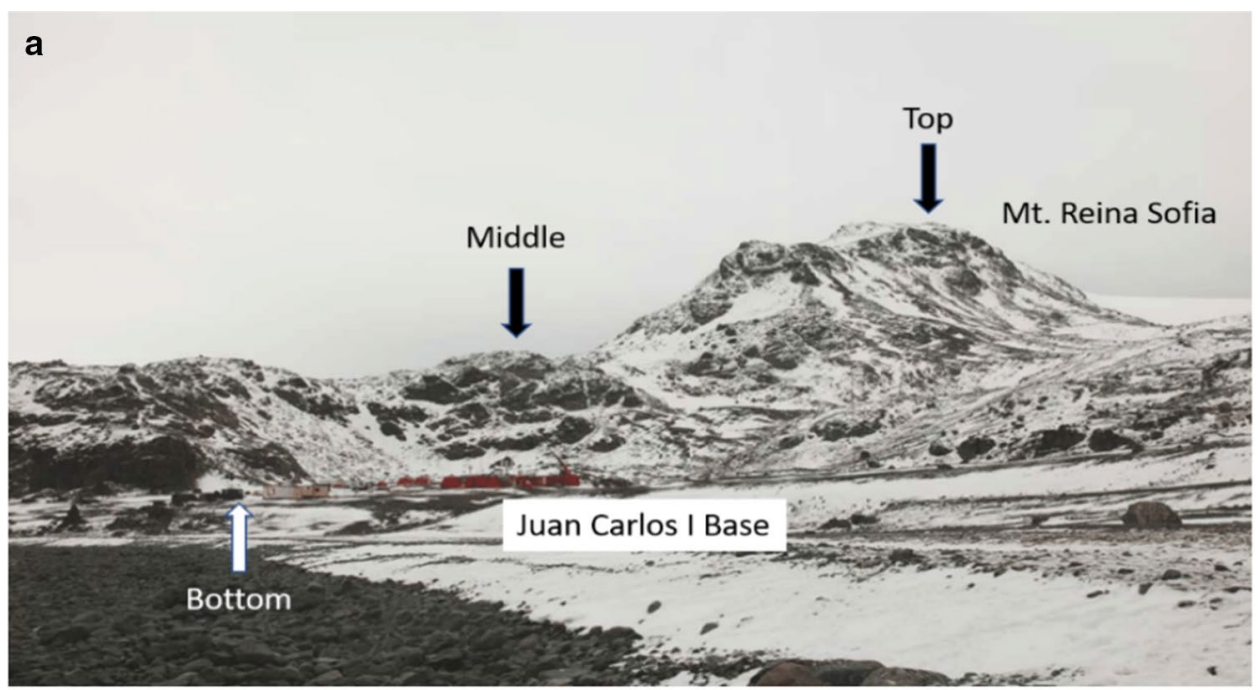

b

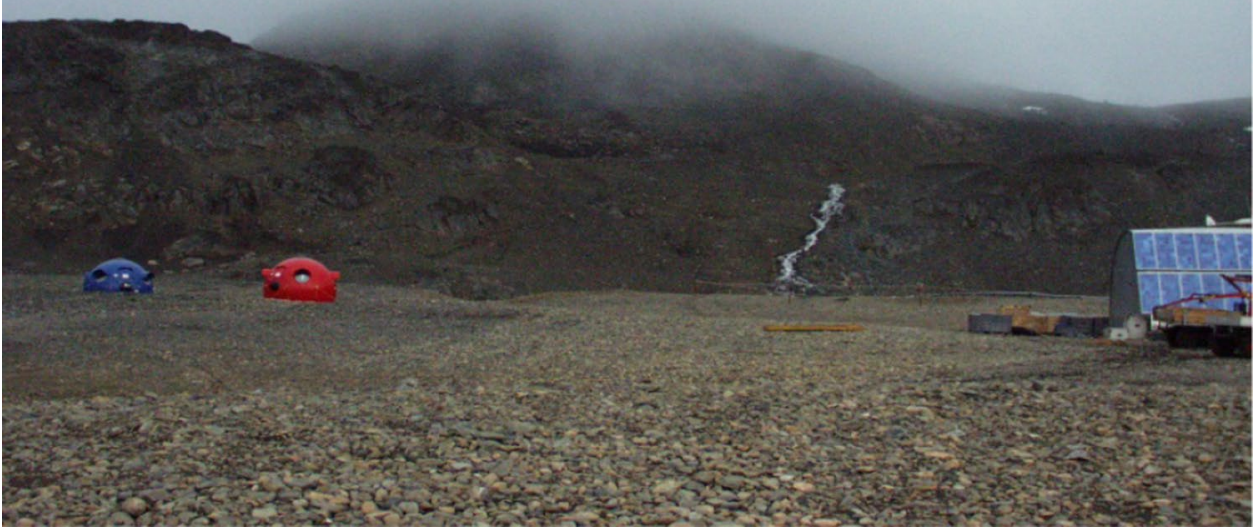

checked regularly to ensure that contact was maintained. Incident light (PPFD, Photosynthetic Photon Flux Density, $\left.\mu \mathrm{mol} \mathrm{m} \mathrm{m}^{-2} \mathrm{~s}^{-1}\right)$ was measured with self-made PPFD sensors (Pontailler 1990) calibrated against a LiCOR 190 SB probe (LiCOR, USA) using an optical calibration unit (LiCOR Li 1800). The PPFD sensors were always fixed adjacent to, and at the same exposure angle as, the investigated cryptogam thallus (Fig. 3b). Limitations in the data loggers meant that PPFD was recorded only over the range 0-2000 $\mu \mathrm{mol} \mathrm{m} \mathrm{m}^{-2} \mathrm{~s}^{-1}$. Air humidity was measured using Vaisala capacity probes (HMP35A; Vaisala, Finland).

\section{Macroclimate}

Macroclimate data, air temperature and relative humidity were obtained from a fixed, permanent weather station $\left(62.65^{\circ} \mathrm{S} 60.38^{\circ} \mathrm{W}, 14 \mathrm{~m}\right.$ asl $)$ at the Juan Carlos I Station (www.aemet.es BAE Juan Carlos I. WMO 89,064). Unfortunately, no data for incident radiation were available for this research period.

\section{Chlorophyll a fluorescence measurements}

Chl $a$ fluorescence of Photosystem II (PSII) was monitored for up to 31 days (periods for individual species and sites were: H. crispulum, bottom, 15 d, 26/01-09/02; middle, 18 
Fig. 3 Pictures of the three sites: a Top site, b Hymenoloma crispulum measurement location at Top site showing fluorescence glass fibre, relative humidity and temperature probe, and quantum sensor; c Middle site; d Usnea aurantiaco-atra measurement location at Middle site; e Bottom site; f $H$. crispulum measurement location at Bottom site

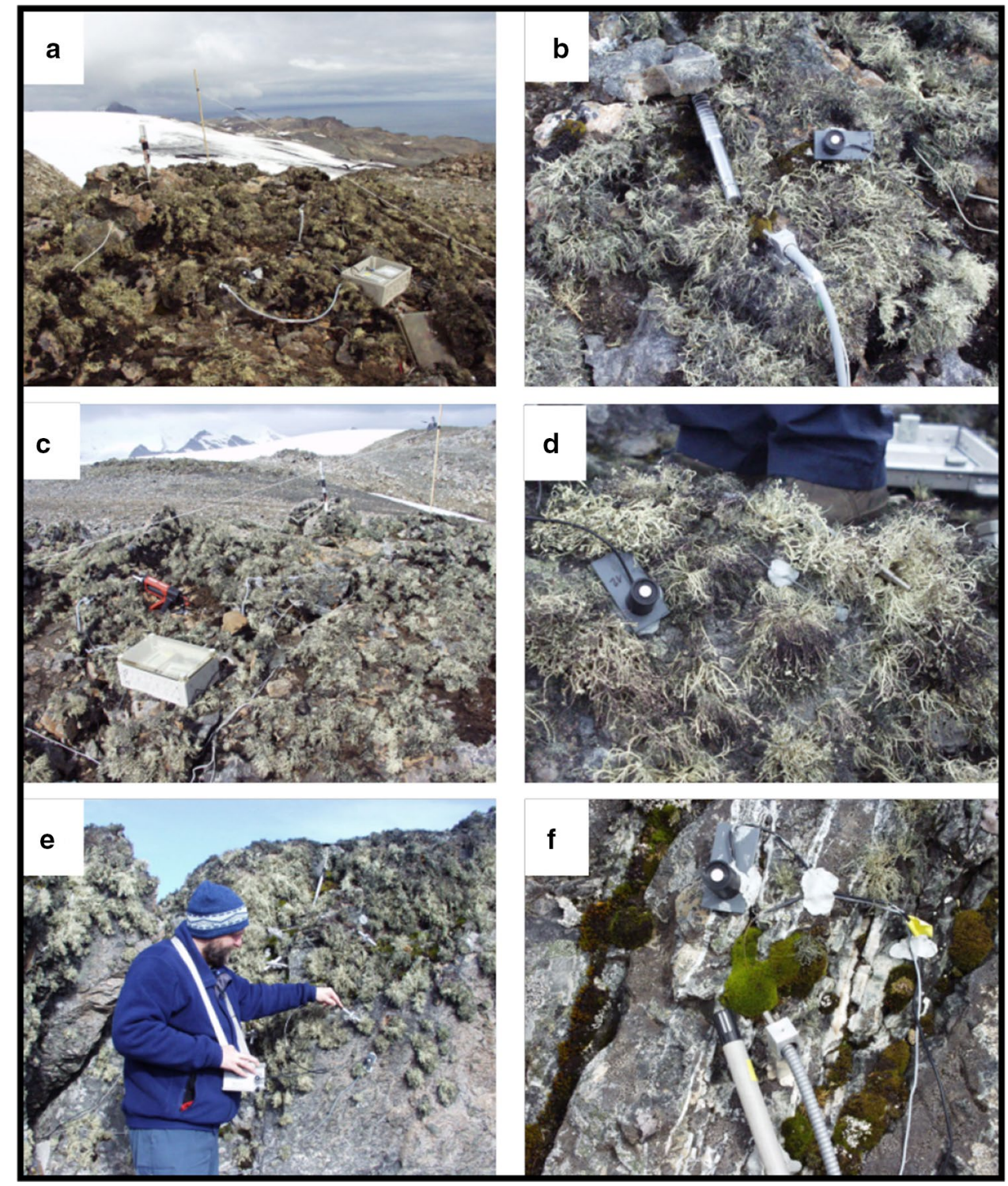

d, 26/01-12/02; top, 20 d, 26/01-14/02; U. aurantiaco-atra: bottom, $31 \mathrm{~d}, 25 / 01-24 / 02$; middle, $25 \mathrm{~d}$, 25/01-18/02; top, $18 \mathrm{~d}, 27 / 01-13 / 02)$. There were occasional equipment problems and the comparison period was set from $29^{\text {th }}$ January to 12 th February (15 days, Julian Day 29 to 42, inclusive). During this period full data sets were obtained for both species at all three sites.

Chlorophyll fluorescence measurements were made at $0.5 \mathrm{~h}$ intervals using a pulse amplitude modulated fluorometer Mini-PAM (Walz, Germany). The fibre optics were mounted in the specially designed fibre optic locators that are fully described in Schlensog and Schroeter (2001) and this layout ensured that fibres were firmly fixed so that, other than due to slight movements by the sample, measurements were always made at exactly the same point, and at exactly the same distance from the thalli. The measuring procedure was that of Schroeter et al. (2017) and was identical at all sites. Whether the photosynthetic systems were active was determined using the saturation pulse method (Schreiber et al. 1995). Momentary chlorophyll fluorescence (F) was first measured by irradiating the samples with a low intensity-modulated light followed by a saturating pulse of actinic light (for about $1 \mathrm{~s}$ at $4000 \mu \mathrm{mol}$ photons $\mathrm{m}^{-2} \mathrm{~s}^{-1}$ ) to induce a maximum value of fluorescence (Fm') with all photosystem II reaction centres closed. Effective photosynthetic yield of PSII ( $\left.\mathrm{Y}_{(\mathrm{II})}\right)$, the proportion of absorbed light in PSII, is calculated as $\mathrm{Y}_{(\mathrm{II})}=\left(\mathrm{Fm}^{\prime}-\mathrm{F}\right) / \mathrm{Fm}^{\prime}=\Delta \mathrm{F} / \mathrm{Fm}^{\prime}$ where $\Delta \mathrm{F}$ is the variable fluorescence (Genty et al. 1989). When thalli are darkened in the night $Y_{(I I)}$ is identical to $\Phi_{\text {PSII }}$, the optimal chlorophyll fluorescence yield. Relative Electron Transport Rate was calculated as ETR $=\mathrm{PPFD} \times \Delta \mathrm{F} / \mathrm{Fm}$ '.

Limitation in amount of equipment and the fact that each Mini-PAM has a single monitoring glass fibre meant that only one sample was monitored for each species at each 
site. Recorded data was downloaded at regular intervals and normally when a full battery was installed.

\section{Fluorescence data handling}

The datasets from the $\mathrm{Chl} a$ fluorescence and microclimate data loggers were aligned to give thallus and air temperatures, relative humidity and incident PPFD for each fluorescence determination. Effective yields of zero are taken to indicate no photosystem II activity and that the lichen was physiologically inactive, whilst $\mathrm{Y}_{\text {(II) }}$ greater than zero indicated an active thallus (Raggio et al. 2014). However, there are problems in interpreting the data because the absolute fluorescence signal strength declines as the thalli desiccate and this, combined with normal machine signal noise, means that low F and Fm' values tend to make $\mathrm{Y}_{(\mathrm{II})}$ unreliable. However, the relatively rapid transition in $\mathrm{Y}_{\text {(II) }}$ when thalli were hydrating or drying meant that this was a minor problem and a positive $\mathrm{Y}_{(\text {II) }}$ was taken to indicate an active thallus (Schlensog et al. 2013; Schroeter et al. 2017). Activity, defined as the proportion (\%) of the time that the thalli were active, i.e. showed a positive photosynthetic signal ( $\mathrm{Y}_{(\mathrm{II})}>0$ ) was calculated as active time/total time of measurements and, also, as a percentage of the time samples were active in light and in the dark. Livingston Island lies just outside the Antarctic Circle, so the length of the night (time between sunset and sunrise) was c. $7.5 \mathrm{~h}$ and PPFD parameters were calculated only for diurnal values (PPFD of $\geq 1 \mu \mathrm{mol}$ photons $\mathrm{m}^{-2} \mathrm{~s}^{-1}$ ).

\section{$\mathrm{CO}_{2}$ gas exchange measurements}

Hymenoloma crispulum: $\mathrm{CO}_{2}$ exchange under controlled laboratory conditions were carried out in the lab at the Spanish base on three replicates for each locality freshly sampled from the field site. An open flow IRGA system (CMS 400, Walz, Germany) was used: $\mathrm{CO}_{2}$ exchange was measured as the difference between the air passed through the cuvette with the sample and the ambient air (Sancho and Kappen 1989; Schroeter et al. 1994, 1995; Pannewitz et al. 2006). Thalli were reactivated in the laboratory for $24 \mathrm{~h}$ in a chamber with $12 \mathrm{~h}$ light $\left(20 \mu\right.$ mol photon $\left.\mathrm{m}^{-2} \mathrm{~s}^{-1}\right) / 12 \mathrm{~h}$ dark, $15{ }^{\circ} \mathrm{C}$, after spraying with water to saturation followed by light shaking to remove excess water. $\mathrm{CO}_{2}$ exchange rates are all presented on a sample surface area basis.

The response of $\mathrm{CO}_{2}$ exchange to thallus water content was measured as the moss dried out in flowing air, $600 \mathrm{~mL} \mathrm{~min}^{-1}$, at a PPFD of $400 \mu \mathrm{mol}$ photon $\mathrm{m}^{-2} \mathrm{~s}^{-1}$ and $10{ }^{\circ} \mathrm{C}$. Samples were removed and weighed at 30 min intervals and thallus water content (WC) was calculated as (wet moss weight—dry moss weight)/dry moss weight and given as percentage by weight. Measurements were continued until $\mathrm{CO}_{2}$ exchange rate had fallen to around $50 \%$ of maximum.
The samples were then weighed after oven-drying overnight at $105^{\circ} \mathrm{C}$. This was an initial study so that later measurements of light response were made at the optimal water content of the samples.

The response of $\mathrm{CO}_{2}$ exchange to photosynthetic photon flux density (PPFD) was determined from measurements made at $0,25,50,100,200,400,600,800$ and $1200 \mu \mathrm{mol}$ photon $\mathrm{m}^{-2} \mathrm{~s}^{-1}$ and repeated at $5,15,20$ and $25^{\circ} \mathrm{C}$; all measurements were done at the previously determined optimal water content. The radiation source was a KL 2500 LCD (Schott) cold light to avoid heating the samples inside the cuvette. The PPFD response curves were analysed by statistical fitting to a Smith function, as detailed in Green et al. (1997).

Nonlinear regression and curve fitting for calculating net photosynthesis from light and temperature data were made using NLREG (PH Sherrod, Brentwood, USA, www.nlreg. com). Regression models were developed using the $\mathrm{CO}_{2}$ exchange data obtained for $\mathrm{H}$. crispulum and the existing data for $U$. aurantiaco-atra from the same site (Schroeter 1997). For H. crispulum there were individual data sets for both Top and Bottom sites but, for U. aurantiaco-atra no data were available for samples from Top site so the Bottom data were used. For this reason, and, also, because of the different bases of the data, dry weight for $U$. aurantiaco-atra and area for $H$. crispulum, inter-specific comparisons are not valid. The models were applied to periods when full data sets were available at both sites for each species for thallus temperature and incident light.

\section{Statistical analysis}

Where required, online statistical testing was used for $t$-tests to compare means and One-way ANOVA to compare site means (Online Statistical Testing, www. Statpages.info). When the overall ANOVA was significant $(p<0.05)$ then a post hoc Tukey's HSD (honestly significant difference) was used to test groups differences. Graphs were produced and analysed using SigmaPlot (Systat Software Inc.).

\section{Results}

\section{Macroclimate}

The overall picture of the macroclimate of Juan Carlos I Station is one of stability for air temperature and air relative humidity (Table 1; Schroeter et al. 2017). Mean temperatures for the months January and February were almost identical at $2.66 \pm 0.12{ }^{\circ} \mathrm{C}$ and $2.70 \pm 0.15^{\circ} \mathrm{C}$, respectively , \pm s.e., $n=31$ and 28$)$ and were not significantly different as, also, were mean maxima, mean minima and range which all differed by $0.22{ }^{\circ} \mathrm{C}$ or less (Table 1). During January and 
Table 1 Macroclimate: air temperature $\left({ }^{\circ} \mathrm{C}\right)$, air relative humidity $(\%)$ and precipitation (mm) for Juan Carlos I Antarctic Base in January and February 2002 and the 12-day comparison period

\begin{tabular}{|c|c|c|c|c|c|}
\hline & & \multicolumn{3}{|c|}{ Months-2002 } & \multirow[b]{2}{*}{$29 / 01$ to $09 / 02^{*}$} \\
\hline & & Jan-Feb & January & February & \\
\hline \multicolumn{6}{|l|}{ Air temperature $\left({ }^{\circ} \mathrm{C}\right)$} \\
\hline \multirow[t]{4}{*}{ Means } & Mean & $2.68 \pm 0.10$ & $2.66 \pm 0.12$ & $2.70 \pm 0.15$ & $2.97 \pm 0.18$ \\
\hline & Maximum & $4.28 \pm 0.17$ & $4.37 \pm 0.25$ & $4.15 \pm 0.22$ & $4.58 \pm 0.36$ \\
\hline & Minimum & $1.47 \pm 0.10$ & $1.48 \pm 0.10$ & $1.45 \pm 0.20$ & $1.78 \pm 0.16$ \\
\hline & Range & $2.81 \pm 0.18$ & $2.89 \pm 0.26$ & $2.70 \pm 0.25$ & $2.81 \pm 0.35$ \\
\hline \multirow[t]{3}{*}{ Absolute } & Maximum & 8.7 & 8.7 & 7.4 & 7.4 \\
\hline & Minimum & -0.7 & 0.6 & -0.7 & 0.8 \\
\hline & Range & 9.4 & 8.1 & 8.1 & 6.6 \\
\hline \multicolumn{6}{|c|}{ Air relative humidity (\%) } \\
\hline \multirow[t]{4}{*}{ Means } & Mean & $79.3 \pm 0.8$ & $78.7 \pm 1.1$ & $80.0 \pm 1.1$ & $78.6 \pm 1.3$ \\
\hline & Maximum & $86.9 \pm 0.6$ & $85.8 \pm 0.9$ & $88.4 \pm 0.5$ & $85.9 \pm 1.3$ \\
\hline & Minimum & $68.2 \pm 1.3$ & $66.8 \pm 1.7$ & $70.2 \pm 1.8$ & $68.7 \pm 1.9$ \\
\hline & Range & $18.7 \pm 1.1$ & $19.0 \pm 1.5$ & $18.2 \pm 1.5$ & $17.3 \pm 1.5$ \\
\hline \multirow[t]{3}{*}{ Absolute } & Maximum & 92 & 92 & 92 & 91 \\
\hline & Minimum & 47 & 47 & 52 & 55 \\
\hline & Range & 45 & 45 & 40 & 36 \\
\hline Precipitation $(\mathrm{mm})$ & & 148.1 & 72.3 & 75.8 & 31.0 \\
\hline
\end{tabular}

Overall means are calculated from daily means (January $n=31$; February $n=28 ; \pm$ s.e.) whilst absolute maxima and minima are the highest or lowest values for each period. Incident radiation information is not available for these months. * period for comparing all sites. Data are from Spanish Meteorological Agency (AEMET) station (https://antartida.aemet.es/). All statistical comparisons, one-way ANOVA comparing January, February, and Comparison period are non-significant
February, the absolute maximum temperature reached was $8.7^{\circ} \mathrm{C}$ and the minimum $-0.7^{\circ} \mathrm{C}$. Mean relative humidity was also very stable, and not significantly different, over the two months at $78.7 \pm 1.1$ and $80.0 \pm 1.1 \%$, January and February, respectively, giving mean ranges of $19.0 \pm 1.5$ and $18.2 \pm 1.5 \%$ (Table 1). Total precipitation for the months was $72.3 \mathrm{~mm}$ and $75.8 \mathrm{~mm}$ falling on 21 and 18 days in January and February, respectively. Incident light was only available from the probes adjacent to the samples (see later section).

Macroclimate for the comparison period, 29th January to 10th February (Julian Days 29 to 40.5) was not significantly different from the months January and February: daily mean air temperature $2.97 \pm 0.18{ }^{\circ} \mathrm{C}(n=12)$, mean minimum and maximum were $1.78 \pm 0.16{ }^{\circ} \mathrm{C}$ and $4.58 \pm 0.36{ }^{\circ} \mathrm{C}$, respectively, a range of only $2.81 \pm 0.35^{\circ} \mathrm{C}$. Mean air relative humidity $(\mathrm{RH})$ was also very stable at $78.6 \pm 1.3 \%$ with mean maxima and minima of $85.9 \pm 1.3$ and $68.7 \pm 1.9 \%$. Over the two months the absolute maximum and minimum were 92.0 and $47.0 \%$, respectively. Mean air temperatures obtained from recordings at the three sites were $1.45 \pm 0.07,1.39 \pm 0.06$ and $3.36 \pm 0.05{ }^{\circ} \mathrm{C}$, Top, Middle and Bottom, respectively, with the Bottom site being significantly warmer than the other two sites $\left(F_{2,1789}=294.6514, p<0.0001\right)$ and $0.37{ }^{\circ} \mathrm{C}$ warmer $(p<0.0001)$ than the macroclimate mean (Table 2a). The lapse rate (decline in temperature in ${ }^{\circ} \mathrm{C}$ per $100 \mathrm{~m}$ increase in altitude) was $0.72{ }^{\circ} \mathrm{C} 100 \mathrm{~m}^{-1}$, bottom to top (Table 2a). Mean air RH were $87.9 \pm 0.4,78.7 \pm 0.5$ and $77.6 \pm 0.6 \%$, Top, Middle and Bottom, with the Top site being significantly higher than the two lower sites which were not significantly different $\left(F_{2,2143}=135.5511\right.$, $p<0.0001$; Table 2a) with the macroclimate mean at the Juan Carlos I meteorological station near the Bottom site being $78.6 \pm 1.3 \%$. Precipitation occurred on 9 of the 12 days with the largest falls on $2 \mathrm{nd}(10.1 \mathrm{~mm})$ and 9 th February (9.3 mm) and a total of $31.0 \mathrm{~mm}$ Table 1, Fig. 4).

\section{Activity}

Activity (positive yield) patterns for the two species and the three sites are presented in Fig. 4 for the comparison period. All records are complete with the exception of a 29 h gap (Julian Day 37.3 to 38.5) for $H$. crispulum Middle (Fig. 4). With the exception of $U$. aurantiaco-atra Top, no sites showed activity at the start of the comparison period until activated by a major precipitation event $(10.3 \mathrm{~mm})$ at Julian Day (JD) 32.2. Usnea aurantiaco-atra Top differed by showing two short periods of activity from JD 30.0-30.4 and 32.9-31.3, both during the night. Following this dry period, which had been continuous for 5 days, two main patterns can be seen: for the three sites $H$. crispulum Bottom and Middle, and U. aurantiaco-atra Top, there is continuous activity, whilst the remaining locations show, often concurrent, periods of inactivity, 5 for $U$. aurantiaco-atra Middle 
Table 2 Mean values for yield, ETR and incident light (PPFD), thallus temperature and relative humidity for all three sites: a $U$. aurantiaco-atra, upper panel: Yield in light and dark, ETR, light (PPFD) when active and inactive and temperature $\left({ }^{\circ} \mathrm{C}\right)$ and relative humidity of the air (\%); lower panel: mean thallus temperature when active and inactive, mean relative humidity when active and inactive; *these values are calculated without the warming event data being included; $\mathbf{b}$ $H$. crispulum, same panel layout except no values for the air

Yield, PPFD, temperature and air relative humidity

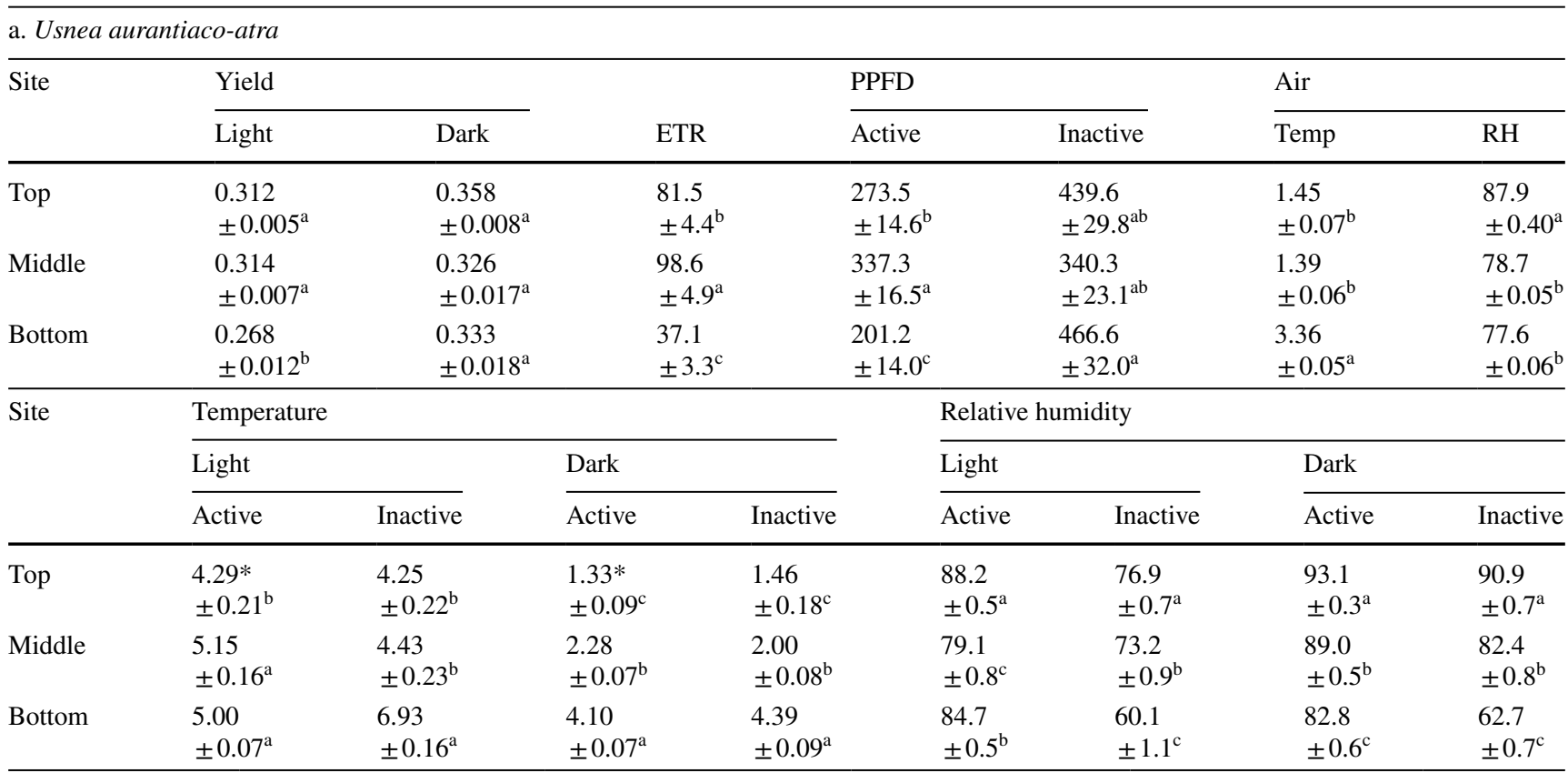

b. Hymenoloma crispulum

\begin{tabular}{|c|c|c|c|c|c|c|c|c|}
\hline \multirow[t]{2}{*}{ Site } & \multicolumn{3}{|c|}{ Yield } & & \multirow[t]{2}{*}{ ETR } & \multicolumn{3}{|l|}{ PPFD } \\
\hline & \multicolumn{2}{|c|}{ Light } & Dark & & & \multicolumn{2}{|l|}{ Active } & Inactive \\
\hline Top & \multicolumn{2}{|c|}{$0.377 \pm 0.007^{b}$} & $0.435 \pm 0.010^{\mathrm{b}}$ & & $101.6 \pm 6.0^{b}$ & \multicolumn{2}{|c|}{$286.7 \pm 16.4^{b}$} & $421.1 \pm 25.0^{\mathrm{a}}$ \\
\hline Middle & \multicolumn{2}{|c|}{$0.451 \pm 0.005^{\mathrm{a}}$} & $0.561 \pm 0.004^{\mathrm{a}}$ & & $147.5 \pm 8.0^{\mathrm{a}}$ & \multicolumn{2}{|c|}{$357.9 \pm 20.5^{\mathrm{a}}$} & $451.2 \pm 39.9^{\mathrm{a}}$ \\
\hline Bottom & \multicolumn{2}{|c|}{$0.360 \pm 0.005^{\mathrm{b}}$} & $0.390 \pm 0.009^{c}$ & & $95.5 \pm 5.4^{\mathrm{b}}$ & $283.7=$ & & $334.5 \pm 32.8^{\mathrm{a}}$ \\
\hline \multirow[t]{3}{*}{ Site } & \multicolumn{4}{|c|}{ Temperature } & \multicolumn{4}{|c|}{ Relative humidity } \\
\hline & \multicolumn{2}{|l|}{ Light } & \multicolumn{2}{|l|}{ Dark } & \multicolumn{2}{|l|}{ Light } & \multicolumn{2}{|l|}{ Dark } \\
\hline & Active & Inactive & Active & Inactive & Active & Inactive & Active & Inactive \\
\hline Top & $\begin{array}{l}3.60 \\
\pm 0.34^{\mathrm{c}}\end{array}$ & $\begin{array}{l}3.85 \\
\pm 0.34^{\mathrm{c}}\end{array}$ & $\begin{array}{l}-0.71 \\
\pm 0.11^{\mathrm{c}}\end{array}$ & $\begin{array}{l}-1.40 \\
\pm 0.12^{\mathrm{c}}\end{array}$ & $\begin{array}{l}86.4 \\
\pm 0.9^{\mathrm{a}}\end{array}$ & $\begin{array}{l}75.1 \\
\pm 1.1^{\mathrm{a}}\end{array}$ & $\begin{array}{l}93.3 \\
\pm 0.4^{\mathrm{b}}\end{array}$ & $\begin{array}{l}88.3 \\
\pm 0.3^{\mathrm{a}}\end{array}$ \\
\hline Middle & $\begin{array}{l}5.23 \\
\pm 0.15^{\mathrm{b}}\end{array}$ & $\begin{array}{l}6.20 \\
\pm 0.36^{\mathrm{b}}\end{array}$ & $\begin{array}{l}2.41 \\
\pm 0.06^{\mathrm{b}}\end{array}$ & $\begin{array}{l}1.35 \\
\pm 0.08^{\mathrm{b}}\end{array}$ & $\begin{array}{l}85.3 \\
\pm 0.7^{\mathrm{a}}\end{array}$ & $\begin{array}{l}69.4 \\
\pm 1.2^{\mathrm{b}}\end{array}$ & $\begin{array}{l}94.9 \\
\pm 0.4^{\mathrm{a}}\end{array}$ & $\begin{array}{l}82.3 \\
\pm 0.5^{\mathrm{b}}\end{array}$ \\
\hline Bottom & $\begin{array}{l}6.18 \\
\pm 0.17^{\mathrm{a}}\end{array}$ & $\begin{array}{l}7.98 \\
\pm 0.47^{\mathrm{a}}\end{array}$ & $\begin{array}{l}2.85 \\
\pm 0.06^{\mathrm{a}}\end{array}$ & $\begin{array}{l}2.61 \\
\pm 0.07^{\mathrm{a}}\end{array}$ & $\begin{array}{l}81.7 \\
\pm 0.8^{\mathrm{b}}\end{array}$ & $\begin{array}{l}62.5 \\
\pm 1.4^{\mathrm{c}}\end{array}$ & $\begin{array}{l}92.0 \\
\pm 0.5^{\mathrm{b}}\end{array}$ & $\begin{array}{l}75.0 \\
\pm 0.7^{\mathrm{c}}\end{array}$ \\
\hline
\end{tabular}

Errors are \pm 1 standard error of the mean; site means followed by different superscript letters are significantly different ( $p<0.05)$, Tukey's HSD (honestly significant difference) following a one-way ANOVA

and Bottom, but only the last 3, for $H$. crispulum Top site (Fig. 4).

Mean activities for $U$. aurantiaco-atra were similar at Bottom and Middle sites being 54.4\% and 57.1\% (Bottom and Middle, respectively), and was considerably higher at the Top site, $82.9 \%$ (Table 3). However, H. crispulum had higher activities at the Bottom and Middle sites, 75.1 and $70.9 \%$, and activity at the Top site was lower, $59.0 \%$.
Activity in the light for U. aurantiaco-atra at the Bottom site at $49.0 \%$, was $17.7 \%$ lower than in the dark, but, at the Middle site, at $61.0 \%$, it was $17.1 \%$ higher. Activity in both light and dark was much higher at the Top site, 80.2 and $90.9 \%$, respectively (Table 3). Hymenoloma crispulum, at the Bottom site showed identical activity in light and dark, $75.1 \%$. At the Middle site activity in the dark, $74.8 \%$, was 5.5\% higher than in the light, whilst, at Top site, activities in both 


\section{Hymenoloma crispulum}

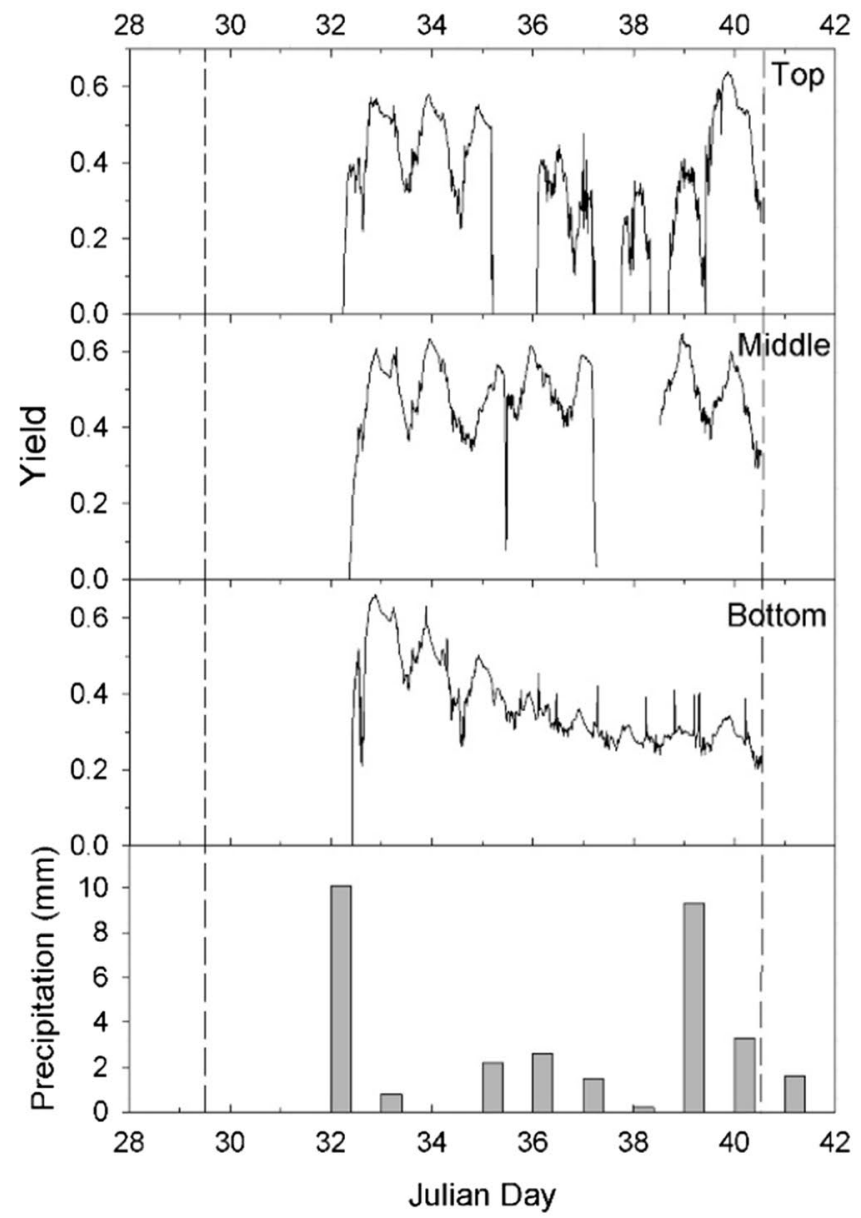

Fig. 4 Daily pattern of yield (upper three panels) and precipitation (bottom panels); left-hand panels, Hymenoloma crispulum; righthand panels, Usnea aurantiaco-atra. For both species: the upper three individual panels are, from the top down: Top site, Middle site and Bottom site, respectively. In all cases the yield is the Y-axis $(0.0$

\section{Usnea aurantiaco-atra}

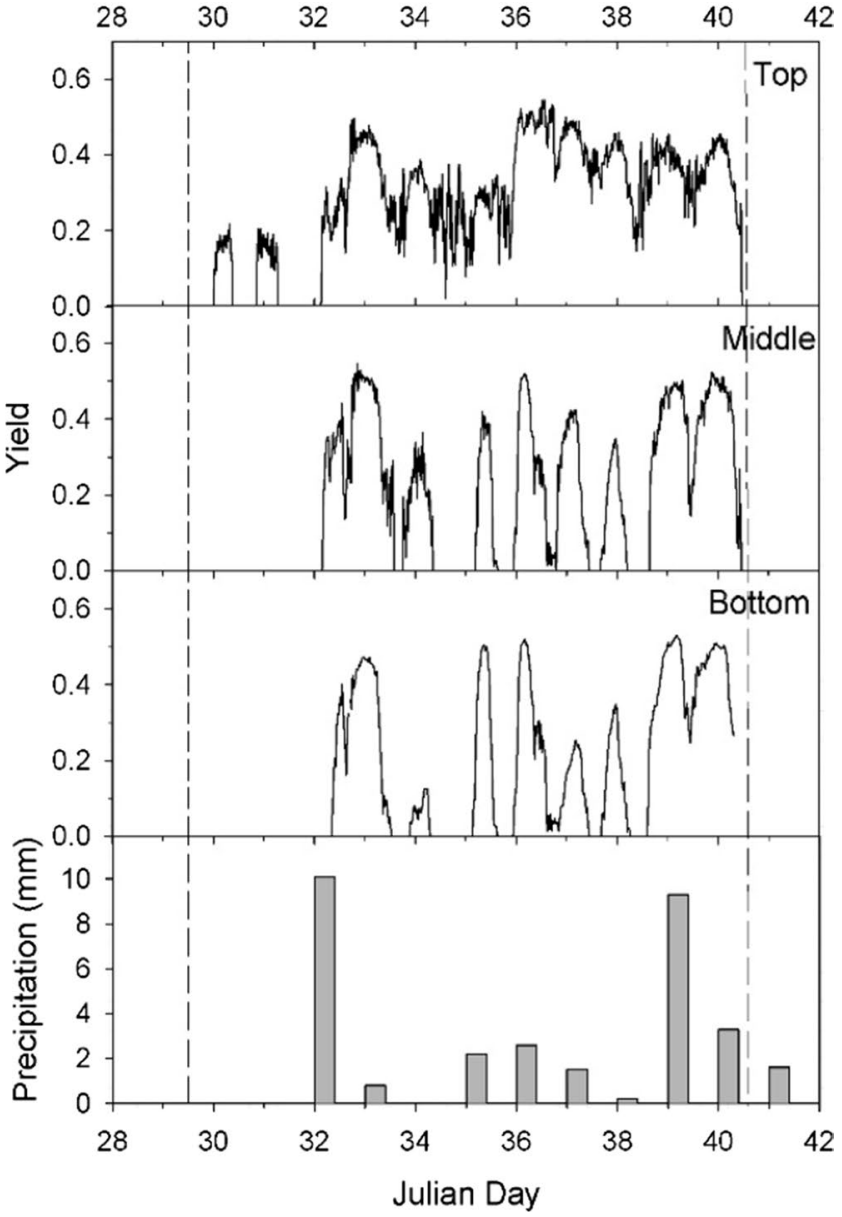

to 0.7 ) and the Julian Days (JD 28 to 42 ) the $X$ axis. Bottom panels (both are identical): total daily precipitation (Y-axis, $\mathrm{mm}$ rain equivalent). The comparison period for the result runs from JD 29 to Day 40, both start and end marked with vertical dashed line in each panel
Table 3 Total activity and activity in light and dark as \% of comparison period, for Usnea aurantiaco-atra (left), and Hymenoloma crispulum (right)

\begin{tabular}{|c|c|c|c|c|c|c|}
\hline \multicolumn{7}{|c|}{ Activity (\%) } \\
\hline \multirow[b]{2}{*}{ Site } & \multicolumn{3}{|c|}{ Usnea aurantiaco-atra } & \multicolumn{3}{|c|}{ Hymenoloma crispulum } \\
\hline & All & Light & Dark & All & Light & Dark \\
\hline Top & 82.9 & 80.2 & 90.9 & 59.0 & 55.0 & 69.5 \\
\hline Middle & 57.1 & 61.0 & 42.9 & 70.9 & 69.3 & 74.8 \\
\hline Bottom & 54.4 & 49.0 & 66.7 & 75.1 & 75.1 & 75.1 \\
\hline
\end{tabular}

light and dark were lower, 55.0 and $69.5 \%$, light and dark, respectively, the reverse situation to $U$. aurantiaco-atra.

\section{Microclimate when active and inactive}

\section{Incident light}

mean incident light (PPFD) when active for $U$. aurantiaco-atra increased in the order Bottom, Top, Middle, with all sites being significantly different $\left(F_{2,2029}=12.7868\right.$, 
$p<0.0001$ ) (Table 2a). Mean light was lower when active than when inactive for all three sites (201.2 versus 466.6, 337.3 vs $340.3,273.5$ vs $439.6 \mu \mathrm{mol} \mathrm{m}^{-2} \mathrm{~s}^{-1}$, active vs inactive, bottom, middle and top sites, respectively, with the differences being highly significant for Bottom and Top sites (both $p<0.0001$; Table 2a). Hymenoloma crispulum had similar mean PPFD when active at Top and Bottom sites, and significantly higher at Middle site $\left(F_{2,1098}=5.4641, p=0.0044\right)$. When inactive, the sites were not significantly different. Light levels were significantly higher when inactive than when active at Middle $\left(t_{503}=2.2946, p=0.0222\right)$ and Top sites $\left(t_{466}=4.4877\right.$, $p<0.0001$; Table 2b).

\section{Thallus temperatures}

Usnea aurantiaco-atra shows a variety of thallus temperature responses depending on site and activity status (Table 2a). In the light, and when active, thallus temperatures were not significantly different between Bottom and Middle (5.00 and $5.15^{\circ} \mathrm{C}$ ) but was significantly lower at Top site $\left(4.29^{\circ} \mathrm{C} ; F_{2,804}=7.0689, p=0.0009\right)$. When inactive in the light, temperatures at Top and Middle sites were not significantly different, 4.25 and $4.43{ }^{\circ} \mathrm{C}$, whilst Bottom site was significantly warmer, $6.93{ }^{\circ} \mathrm{C}(p<0.0001)$. Temperatures when active not were significantly different to those when inactive at the Top site, but were significantly different at Middle and Bottom sites, lower and higher, respectively $\left(t_{631}=2.6495, p=0.0083 ; t_{351}=10.9007, p<0.0001\right)$. In the dark, temperatures at all three sites, active and inactive, were significantly different $\left(F_{2,276}=354.5304, p<0.0001\right.$; $\left.F_{2,176}=192.7072, p<0.0001\right)$ and declined with increase in altitude (Table 2a). Temperatures when active were significantly different from inactive at Bottom (lower) and Middle (higher) sites $\left(t_{154}=2.4637, p=0.0149 ; t_{185}=2.5533\right.$, $p=0.0115$ ) but not at Top site. Lapse rates, bottom to top,

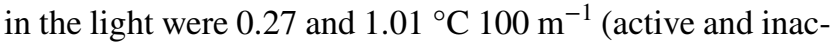
tive) and were higher in the dark, 1.04 and $1.10{ }^{\circ} \mathrm{C} 100 \mathrm{~m}^{-1}$ (active, inactive, respectively). Lapse rate for all data regard-

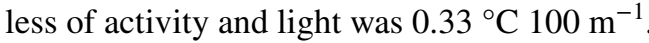

Mean thallus temperatures for $H$. crispulum declined significantly with increase in altitude in the light when active $\left(6.18,5.23\right.$ and $\left.3.60{ }^{\circ} \mathrm{C} ; F_{2,1098}=33.4495, p<0.0001\right)$, dark and active $\left(F_{2,447}=590.3952, p<0.0001\right)$ and also dark and inactive $\left(F_{2,174}=456.1826, p<0.0001\right.$; Table $\left.2 b\right)$. For light and inactive, the mean temperatures were not significantly different between the Bottom and Middle sites whilst the Top site was significantly lower $(p<0.0001)$. Lapse rates, bottom to top, were $0.97,1.55,1.34$ and $1.51{ }^{\circ} \mathrm{C} 100 \mathrm{~m}^{-1}$ for light active, inactive and dark active, inactive, respectively. Overall lapse rate in the dark for all data was $1.16{ }^{\circ} \mathrm{C}$ $100 \mathrm{~m}^{-1}$.

\section{Air relative humidity}

For U. aurantiaco-atra, mean relative humidity was always significantly different between the three sites whether light/dark or active/inactive (Table $2 \mathrm{a}$; all $p<0.0001$ ). Mean RH was always highest at the Top site and declined with altitude except for Middle site, light and active, which had the lowest RH. Mean RH was always higher when active in both the light and dark (all significant $p<0.0001)$. Hymenoloma crispulum, when inactive in both light and dark had the highest RH at Top site and RH declined with altitude with all sites being significantly different (all $p<0.0024)$. When active in the light Top and Middle sites were not significantly different but higher than Bottom site $\left(F_{2,1098}=9.7874, p=0.0001\right)$. When active in the dark the highest mean RH was at Middle site and was significantly different from the other two sites whilst RH at the Top and Bottom sites were not significantly different $\left(F_{2,174}=183.56, p<0.0001\right.$; Table $\left.2 b\right)$. Mean RH when inactive were always significantly different and lower than when active (all $p<0.0001$ ).

\section{Activity distribution with respect to microclimate.}

\section{Thallus temperature}

Distribution of activity with thallus temperature was analysed by allocating activity to $1{ }^{\circ} \mathrm{C}$ categories of thallus temperature (Fig. 5). In the dark, both species showed an obvious shift to lower temperatures with increase in altitude (Fig. 5c, d; Table 2; $p<0.0001$ ) and temperature range when active was constrained to about $4{ }^{\circ} \mathrm{C}$ for both species and all sites. At the Top site $H$. crispulum was active only at temperatures at, and below, $0{ }^{\circ} \mathrm{C}$ but, at the Middle and Bottom sites, activity was at and above, $0{ }^{\circ} \mathrm{C}$, as was $U$. aurantiacoatra at all sites. In the light, the spread of thallus temperatures was much larger, whether active or inactive, and the decline with increase in altitude, although present, was less clear (Fig. 5a,b). Hymenoloma crispulum had activity spread over around $15^{\circ} \mathrm{K}$ but with activity at subzero temperatures only at Top site (Fig. 5a). The spread of temperatures was smaller for $U$. aurantiaco-atra and only $7^{\circ} \mathrm{K}$ at the bottom site (Fig. 5b).

\section{Air relative humidity}

There is a clear concentration of activity at higher $\mathrm{RH}$ (Online Resource ESM 1) again with differences in distribution depending on site and species. For $U$. aurantiacoatra, activities at the Middle and Top sites were highest at $90-100 \%$ category and extended down to $50-60 \%$ category. 
Fig. 5 Distribution of a. thallus temperatures for Hymenoloma crispulum (left-hand panels, a and c) and Usnea aurantiacoatra (right-hand panels, $\mathbf{b}$ and d); in the light (upper panels, $\mathbf{a}$ and $\mathbf{b}$ ) or in the dark (lower panels, $\mathbf{c}$ and d). Within each of the four blocks of panels (a, $\mathbf{b}, \mathbf{c}$ and $\mathbf{d})$ the upper subpanel is Top site, centre subpanel is Middle site, and lower subpanel is Bottom site. The bars represent the proportion (\%) of the total number of measurements within each category while active (black bars) or inactive (grey bars). Each category is a $1{ }^{\circ} \mathrm{C}$ range with the bars centred on the chosen temperature i.e. bar at a temperature of $5.0^{\circ} \mathrm{C}$ is for the temperature range 4.5 to $5.5^{\circ} \mathrm{C}$. Solid vertical lines within the panels indicate a temperature of $0{ }^{\circ} \mathrm{C}$, dashed vertical lines indicate the mean temperature when active (note: for $U$. aurantiaco-atra the means for Top active, light and dark, are calculated without the data for the warming event, see Fig. 9)
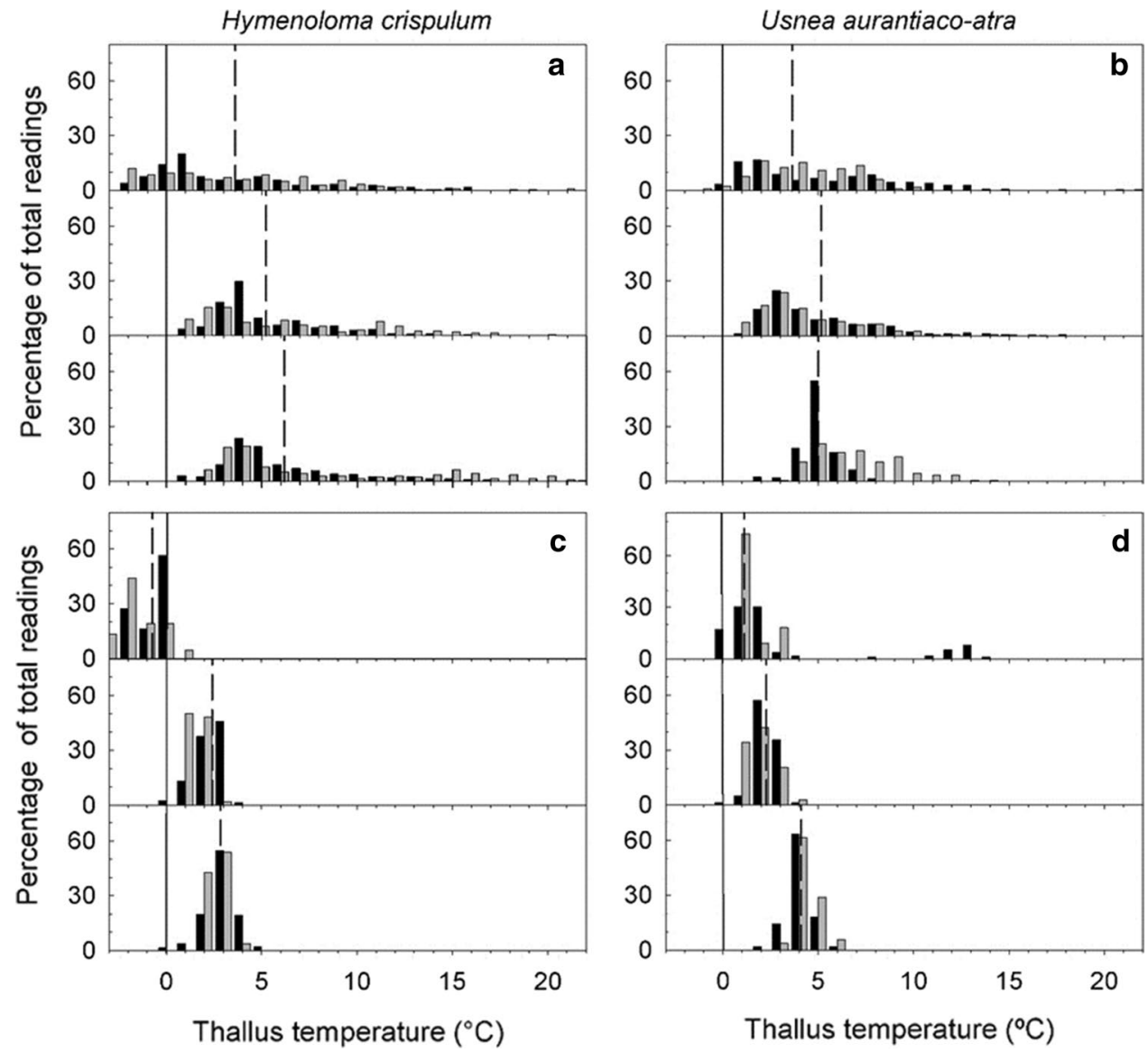

However, activity was much more strongly constrained at the Bottom site with almost all activity at $80-90 \%$ and none below $70 \%$. In contrast, $H$. crispulum showed highest activity at $90-100 \%$ category for all sites and extending down to the $30-40 \%$ category.

\section{Incident light}

Individual data when active in the light were allocated to $100 \mu \mathrm{mol} \mathrm{m}{ }^{-2} \mathrm{~s}^{-1}$ categories as a proportion (\%) of total number of data points and distributions depended on both site and species and, in all cases a high proportion of the data was at low incident light levels (Online Resource ESM 1).

\section{Chlorophyll a fluorescence parameters}

Chlorophyll $a$ yield ( $\left.\mathrm{Y}_{(\mathrm{II})}\right)$ : mean values for yield for both species and all three sites are given in Table 2 and distributions in Table 4 . In the light, $U$. aurantiaco-atra had a significantly lower mean yield at the Bottom site, 0.268, whilst Top and Middle sites were not significantly different ( 0.312 and $\left.0.314 ; F_{2,1029}=8.5215, p<0.001\right)$. In the dark, in contrast, all three sites had similar yields $\left(F_{2,390}=1.6896\right.$, $p=0.1859$ ). Mean yields were always higher in the dark, the difference being significant for the Top and Bottom sites $(p<0.0001$ and $=0.0020)$. Hymenoloma crispulum had higher yields than $U$. aurantiaco-atra at each site and in both light and dark. Middle site in the light was significantly higher than Top and Bottom sites (Table 2b; $\left.F_{2,1108}=73.7532, p<0.0001\right)$. Yields were higher in the dark but, in a complete contrast to U. aurantiaco -atra, the difference between all three sites was highly significant $\left(F_{2,478}=125.0300, p<0.0001\right)$.

The two species showed different patterns in the distribution of yields across yield categories with 0.1 interval, 0.1 to 0.7, at the three sites (Table 4; Online resource ESM 2). In the light, $H$. crispulum the higher yield categories were at and below the mean yield at Bottom site, but at and above the mean yield at Middle and Top sites. Usnea aurantiacoatra had a broader yield distribution at Bottom site, 0.1 to 0.5 , and category percentages around $20 \%$. At Middle and Top sites, the higher categories were 0.3 and 0.4. In the dark, for all sites except $H$. crispulum Bottom, the higher yield categories were above the mean yields. The highest category was 0.6 , and this was exceptionally high for $H$. crispulum Middle site and $U$. aurantiaco-atra Top sites, at over 60 and $50 \%$ of total yields. The H. crispulum Bottom 
Table 4 Allocation of effective photosynthetic yield of Photosystem II (Y(II)) and relative electron transport rate (ETR) to $\mathrm{Y}_{\text {(II) }}$ categories (0.1 to 0.7) for Hymenoloma crispulum, upper panel, and Usnea aurantiaco-atra, lower panel, at the three sites, Top, Middle and Bottom

\begin{tabular}{|c|c|c|c|c|c|c|c|c|c|c|c|c|c|c|}
\hline \multirow{3}{*}{$\begin{array}{l}\text { Hyme- } \\
\text { noloma } \\
\text { crispulum }\end{array}$} & \multicolumn{5}{|l|}{ Top } & \multicolumn{5}{|c|}{ Middle } & \multicolumn{4}{|c|}{ Bottom } \\
\hline & \multicolumn{2}{|c|}{ Yield } & \multicolumn{3}{|l|}{ ETR } & \multicolumn{2}{|c|}{ Yield } & \multicolumn{3}{|l|}{ ETR } & \multicolumn{2}{|c|}{ Yield } & \multicolumn{2}{|l|}{ ETR } \\
\hline & No & $\%$ & Amount & Total & Category & No & $\%$ & Amount & Total & Category & No & $\%$ & Amount & Total \\
\hline 0.1 & 5 & 1.5 & 16 & 81 & 0.1 & 7 & 2.0 & 8 & 59 & 0.1 & 3 & 0.7 & 8 & 23 \\
\hline 0.2 & 28 & 8.5 & 27 & 753 & 0.2 & 2 & 0.6 & 39 & 77 & 0.2 & 6 & 1.4 & 13 & 79 \\
\hline 0.3 & 55 & 16.8 & 72 & 3947 & 0.3 & 9 & 2.6 & 144 & 1300 & 0.3 & 143 & 33.0 & 89 & 12,742 \\
\hline 0.4 & 100 & 30.5 & 152 & 15,210 & 0.4 & 55 & 15.7 & 250 & 13,754 & 0.4 & 157 & 36.3 & 86 & 13,566 \\
\hline 0.5 & 72 & 22.0 & 148 & 10,624 & 0.5 & 170 & 48.6 & 188 & 32,034 & 0.5 & 68 & 15.7 & 161 & 10,945 \\
\hline 0.6 & 59 & 18.0 & 43 & 2542 & 0.6 & 102 & 29.1 & 42 & 4287 & 0.6 & 35 & 8.1 & 83 & 2890 \\
\hline 0.7 & 9 & 2.7 & 16 & 145 & 0.7 & 5 & 1.4 & 23 & 115 & 0.7 & 21 & 4.8 & 21 & 433 \\
\hline Total & 328 & 100 & 474 & 33,303 & & 350 & 100 & 695 & 51,626 & 2.8 & 433 & 100.0 & 460 & 40,679 \\
\hline $\begin{array}{l}\text { Usnea } \\
\text { aurantiaco- } \\
\text { atra }\end{array}$ & Top & & & & Middle & & & & & Bottom & & & & \\
\hline 0.1 & 5 & 1.1 & 4 & 18 & 0.1 & 42 & 10.9 & 16 & 687 & 0.1 & 40 & 23.0 & 17 & 664 \\
\hline 0.2 & 67 & 14.2 & 35 & 2358 & 0.2 & 42 & 10.9 & 73 & 3057 & 0.2 & 17 & 9.8 & 29 & 491 \\
\hline 0.3 & 147 & 31.1 & 102 & 14,941 & 0.3 & 85 & 22.0 & 89 & 7576 & 0.3 & 33 & 19.0 & 65 & 2132 \\
\hline 0.4 & 153 & 32.3 & 85 & 12,982 & 0.4 & 88 & 22.8 & 155 & 13,638 & 0.4 & 39 & 22.4 & 56 & 2168 \\
\hline 0.5 & 81 & 17.1 & 65 & 5293 & 0.5 & 92 & 23.8 & 112 & 10,283 & 0.5 & 40 & 23.0 & 26 & 1023 \\
\hline 0.6 & 20 & 4.2 & 147 & 2942 & 0.6 & 37 & 9.6 & 76 & 2806 & 0.6 & 5 & 2.9 & 32 & 160 \\
\hline 0.7 & 0 & 0.0 & 0 & 0 & 0.7 & 0 & 0.0 & 0 & 0 & 0.7 & 0 & 0.0 & 0 & 0 \\
\hline Total & 473 & 100.0 & 438 & 38,535 & & 386 & 100.0 & 521 & 38,049 & & 174 & 100.0 & 223 & 6638 \\
\hline
\end{tabular}

Yield categories are the left-hand column; $\mathrm{Y}_{(\mathrm{II})}$ are allocated as aa percentage of the total number of readings (\%) for values in the light and dark; ETR are given as the mean value in each yield category (Mean) and as the total ETR in each yield category (Total). The values in bold below the ETR Total column are the grand total for that site for the comparison period

site had its higher categories below the mean and these were around $25 \%$ of yields at 0.3 and 0.4 categories. The species differed by $H$. crispulum always having some yields in the 0.7 category ( 0.6 to 0.7 ) whilst $U$. aurantiaco-atra never did.

Mean relative Electron Transport Rate (ETR) was, for both species, highest at the Middle site and lowest at the Bottom site. For $U$. aurantiaco-atra, ETR was significantly different between all sites $\left(F_{2,1029}=25.3596, p<0.0001\right)$ whilst, for $H$. crispulum, ETR was significantly higher at the Middle site than at Top and Bottom sites which, themselves, were not significantly different $\left(F_{2,1098}=19.1183\right.$, $p<0.001$ ). When ETR is related to incident PPFD (Fig. 6) the upper boundary of the plots (the maximal ETR at any particular light level) was linear or near-linear and, in some cases (U. aurantiaco-atra Top, $H$. crispulum, Top, Bottom and Middle) showed little sign of saturation at full sunlight, $>1500 \mu \mathrm{mol} \mathrm{m}^{-2} \mathrm{~s}^{-1}$. The slope of this boundary (top left of each panel in the Figure) is the yield and, for $H$. crispulum values were very similar, around $0.41-0.44$, at all three sites. Usnea aurantiaco-atra had similar values for the Bottom and Middle sites, 0.32 and 0.36 , but a higher yield at the Top site, 0.47. In the ETR response to PPFD, the upper border at any particular PPFD marks the maximal ETR and maximal yield. Any data points at the same PPFD but below the maximum ETR indicate a lower yield and limitation by another factor, the most likely being low water content. Usnea aurantiaco-atra shows a much greater dispersion of data points (i.e. data points lying away from the maximal line) than $H$. crispulum. The species also shows a fall in maximal light from Top site (close to $2000 \mu \mathrm{mol} \mathrm{m} \mathrm{m}^{-2} \mathrm{~s}^{-1}$ ) through Middle site $\left(1500 \mu \mathrm{mol} \mathrm{m} \mathrm{m}^{-2} \mathrm{~s}^{-1}\right)$ to Bottom site $\left(1000 \mu \mathrm{mol} \mathrm{m}^{-2} \mathrm{~s}^{-1}\right)$. In contrast, the responses of H. crispulum show less dispersion of data points, with least for Middle site, and highest light $\geq 1800 \mu \mathrm{mol} \mathrm{m}^{-2} \mathrm{~s}^{-1}$ ).

Table 4 gives the total ETR for each Yield category and the overall total for all three sites and both species. Total ETR ( $\mu \mathrm{mol}$ electrons $\mathrm{m}^{-2} \mathrm{~s}^{-1}$ ) for $H$. crispulum were highest at Middle site, 51,626, then 40,679 at Bottom site and lowest, 33,303 at Top site. Usnea aurantiaco-atra had almost identical total ETR at Top, 38,535, and Middle, 38,049, sites but a very much lower total at Bottom site, 6638. The distribution of total ETR within each yield 
Fig. 6 ETR (Y axes) versus incident light (X axes, $\mu$ mol $\mathrm{m}^{-2} \mathrm{~s}^{-1}$ ) for Hymenoloma crispulum (left-hand panels) and Usnea aurantiaco-atra (right-hand panels) at the Top, Middle and Bottom sites (upper, centre and lower panels, respectively); data are from the Julian Day 29 to Day 40 comparison period. The dashed lines mark the upper boundary for ETR of each data set which are linear or near-linear and the inserted number (upper left in each panel) is the slope of the line which is the yield

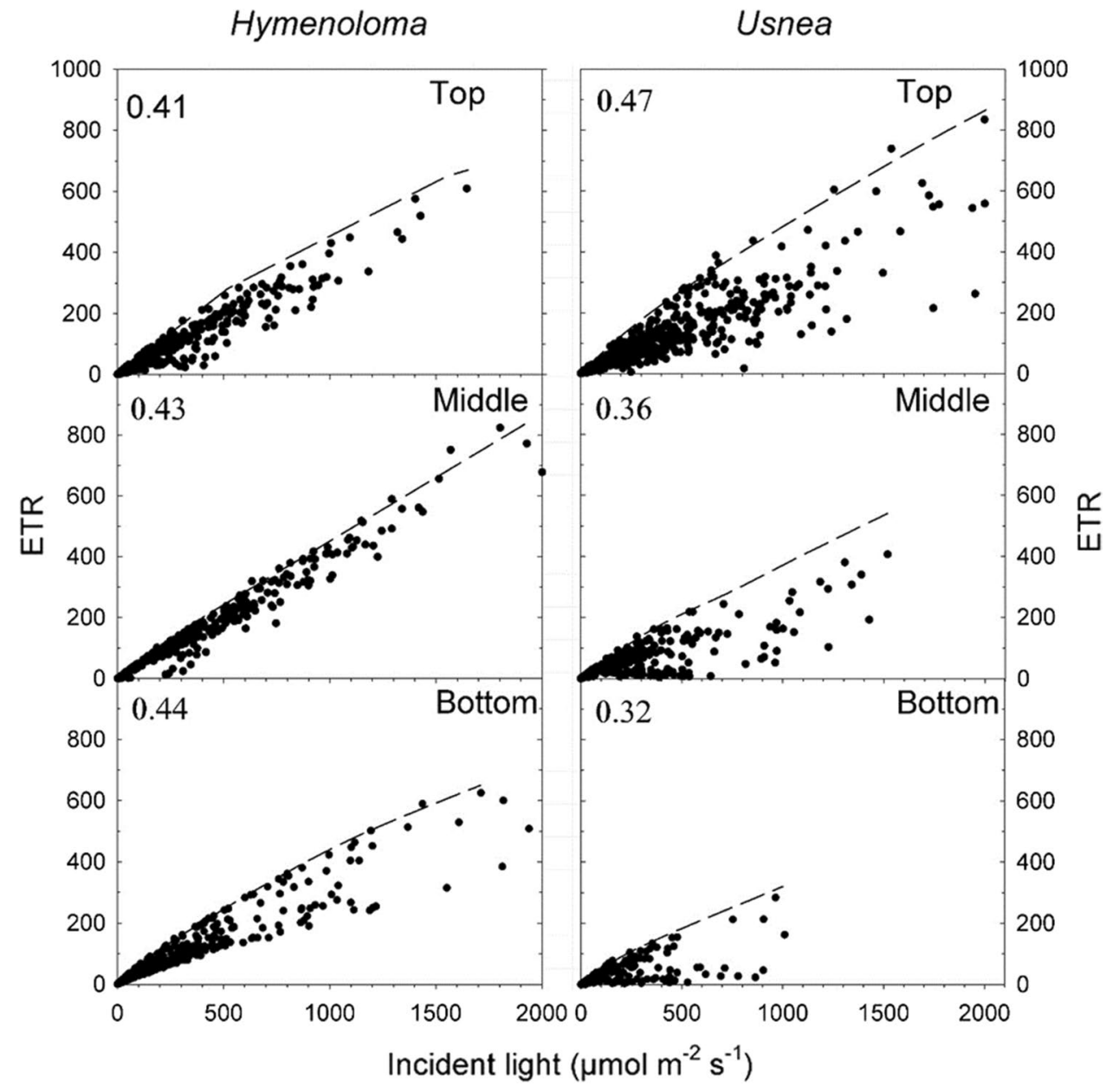

category for $H$. crispulum was always greatest in the categories 0.4 and 0.5 with 0.3 also making a high contribution at Bottom site. For U. aurantiaco-atra the higher categories were 0.3 and 0.4 at Top and Bottom sites, and 0.4 and 0.5 at Middle site. Usnea aurantiaco-atra at Bottom site had very low ETR totals for each category, often $<15 \%$ of the other site values. Total ETR per yield category was lower in the yield range 0.0 to 0.2 , which was not unexpected, due to the low yields nullifying any high PPFD values. However, the category 0.6 also had low ETR totals, and this indicates that these high yields occurred at low light.

\section{$\mathrm{CO}_{2}$ exchange}

Gross photosynthetic rate $(\mathrm{Pg})$ for $H$. crispulum showed a linear response to temperature from the lowest measured temperature, $-2{ }^{\circ} \mathrm{C}$, to the highest $25^{\circ} \mathrm{C}$ (Fig. 7). Pg at the Bottom site was significantly higher at all temperatures than at the Top site $(z=-2.3664, p=0.0180)$. Over the same temperature range dark respiration $(\mathrm{Rd})$ showed an exponential increase in rate and was also higher at the Bottom site $(z=-2.3664, p=0.0180)$. Net photosynthetic rate $(\mathrm{Pn})$ showed the same form of response to temperature at Bottom and Top sites with both having a clear optimum which were almost identical, $11.4^{\circ} \mathrm{C}$ and $11.2{ }^{\circ} \mathrm{C}$, respectively. Pn were always higher for the Bottom site $(z=-1.992, p=0.046)$.

Pn response to light (PPFD, $\mu \mathrm{mol} \mathrm{m} \mathrm{m}^{-2} \mathrm{~s}^{-1}$ ) was measured at 3 temperatures, $-1.5,10$ and $25{ }^{\circ} \mathrm{C}$, for $H$. crispulum samples from the Top and Bottom sites (Fig. 7). All curves showed a typical saturation response with maximal Pn at saturation always being higher at all three temperatures for the Bottom samples. Saturation was achieved at relatively low PPFD of 50, 150 and $400 \mu \mathrm{mol} \mathrm{m}^{-2} \mathrm{~s}^{-1}$ at $-1.5,10$ and $25{ }^{\circ} \mathrm{C}$, respectively, and were identical for the Bottom and Top samples Top samples had lower compensation points than Bottom samples at $-1.5{ }^{\circ} \mathrm{C}$ and $10{ }^{\circ} \mathrm{C}, 4$ and 16 versus 10 and $24 \mu \mathrm{mol} \mathrm{m} \mathrm{m}^{-2} \mathrm{~s}^{-1}$ reflecting higher $\mathrm{Rd}$ at the Bottom site. In contrast, at $25^{\circ} \mathrm{C}$, the compensation point was higher for the Top sample, 168 versus $68 \mu \mathrm{mol} \mathrm{m} \mathrm{m}^{-2} \mathrm{~s}^{-1}$ and these changes in compensation point value reflect the different $\mathrm{Rd}$ of the samples and, also, a lower quantum efficiency (initial slope of the response line) at $25^{\circ} \mathrm{C}$. 


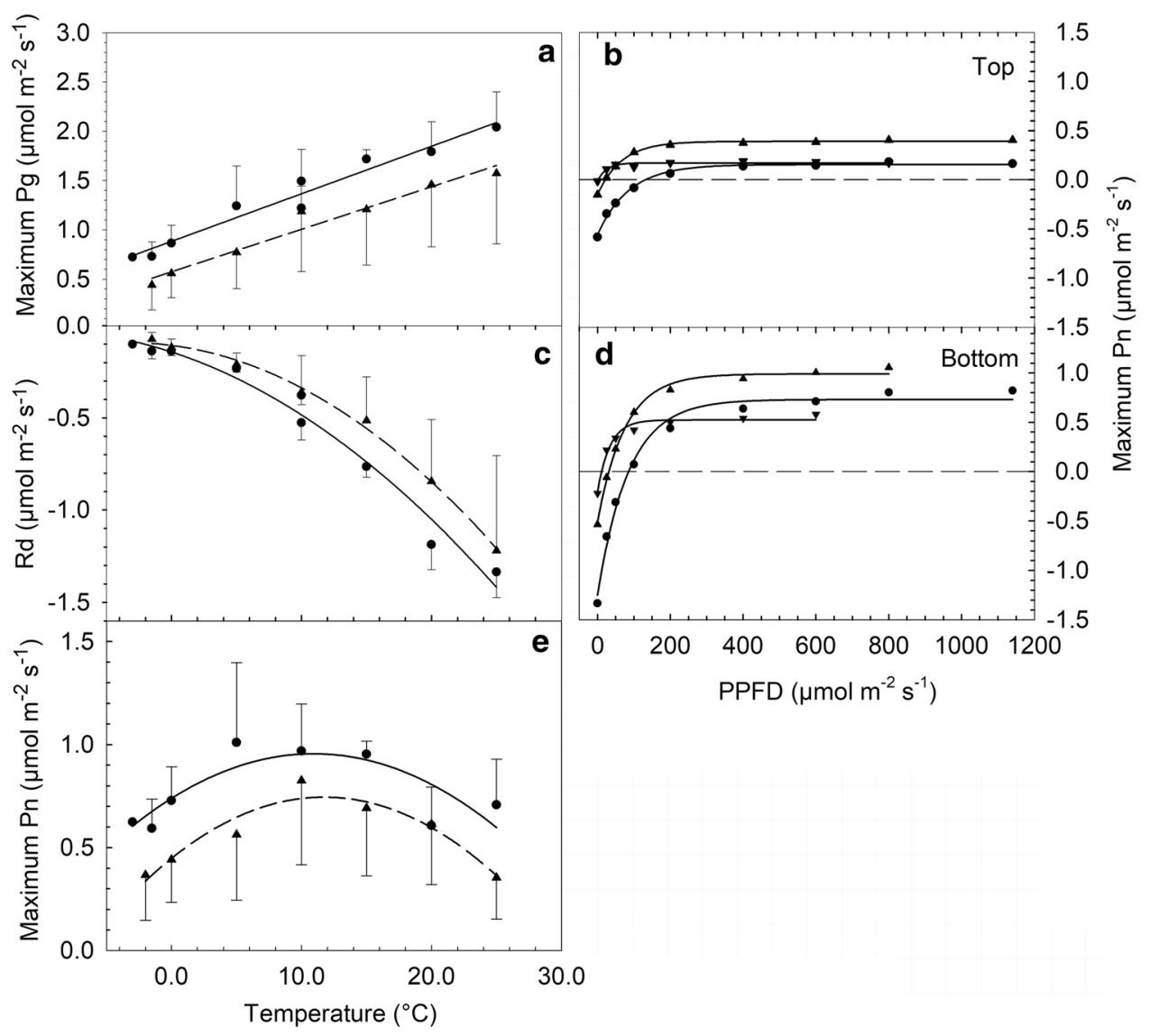

Fig. 7 Response of $\mathrm{CO}_{2}$ exchange to temperature and light for Hymenoloma crispulum. Left-hand panels (a, c and e), panel a - gross photosynthesis, Pg; panel c - dark respiration, Rd; and panel d - net photosynthesis, Pn, at Bottom site (circle, solid line) and Top site (top point triangle, dashed line), In all cases rates are $\mu \mathrm{mol} \mathrm{CO}_{2} \mathrm{~m}^{-2} \mathrm{~s}^{-1}$, and error bars are \pm 1 s.e. (upper bar only on upper line, lower bar only on lower line). The fitted regression lines are all significant, for maximal gross photosynthesis and dark respiration $(p<0.0001$,

Non-linear $\mathrm{CO}_{2}$ exchange models were successfully developed for both $U$. aurantiaco-atra $\left(r^{2}=0.9435\right)$ and $H$. crispulum $\left(r^{2}=0.9790\right.$ and 0.9351 , Bottom and Top) for the periods JD 29 to 45 and JD 27 to 36, respectively. Totals for carbon gain and loss for these periods are given in Fig. 8 in two forms, first, Model, calculated from temperature and light assuming the samples were always active, and second, Model + Yield, where the Model output is adjusted to remove non-active times (yield values of zero) and for degree of activation by multiplying the Model output by $\mathrm{Y}_{\text {(II) }} / 0.6$ ( 0.6 is chosen to indicate maximal photosynthesis). The adjusted output is about $30-40 \%$ lower for $\mathrm{H}$. crispulum and about $70 \%$ lower for U. aurantiaco-atra and this is used in the following comparisons for carbon exchange over the selected time periods. Usnea aurantiaco-atra had a net carbon gain of $51.9 \mathrm{mmol} \mathrm{kg}^{-1}$ at Top site and a net loss of $15.4 \mathrm{mmol} \mathrm{kg}^{-1}$ at Bottom site. The latter loss was driven $r^{2}=0.950$ ), and for maximal net photosynthesis (top site: $p=0.006$, $r^{2}=0.920$; bottom site $\left.p=0.039, r^{2}=0.545\right)$. Right-hand panels $(\mathbf{b}$, d), response of maximal net photosynthesis $\left(\mu \mathrm{mol} \mathrm{CO} \mathrm{CO}_{2} \mathrm{~m}^{-2} \mathrm{~s}^{-1}\right)$ to incident light (PPFD; $\mu \mathrm{mol} \mathrm{m} \mathrm{m}^{-2} \mathrm{~s}^{-1}$ ) at three thallus temperatures ( $-1.5^{\circ} \mathrm{C}$ down point triangle, $10.0{ }^{\circ} \mathrm{C}$ top point triangle and $25.0{ }^{\circ} \mathrm{C}$ circle) at the Top site (upper panel, b) and Bottom site (lower panel, d). Fitted regressions are all highly significant $\left(p<0.0009, r^{2}>0.910\right)$

by lower carbon gain, over 4 times higher at Top site, 90.1 versus $21.3 \mathrm{mmol} \mathrm{CO}_{2} \mathrm{~kg}^{-1}$, as carbon losses were similar, 38.2 versus $36.6 \mathrm{mmol} \mathrm{CO}_{2} \mathrm{~kg}^{-1}, 29.8$ and $63.3 \%$ of total carbon exchange ( $\mathrm{Pg})$, Top and Bottom, respectively. Hymenoloma crispulum had a positive net carbon gain at both sites with $56.2 \mathrm{mmol} \mathrm{CO}_{2} \mathrm{~m}^{-2}$ at the Top site being about $65 \%$ of that at Bottom, $84.3 \mathrm{mmol} \mathrm{CO}_{2} \mathrm{~m}^{-2}$. Carbon loss, as a proportion of total carbon exchange, was much lower than for U. aurantiaco-atra at 5.8 and $14,8 \%$, Top and Bottom.

\section{Warming event}

On JD 33 and 34 the monitoring systems reported an unusual temperature event only for $U$. aurantiaco-atra at the Top site (Fig. 9). Typically, the thallus temperature of $U$. aurantiacoatra was slightly warmer than $H$. crispulum and this was the situation until noon, JD 33 (2nd February) after which the $U$. 


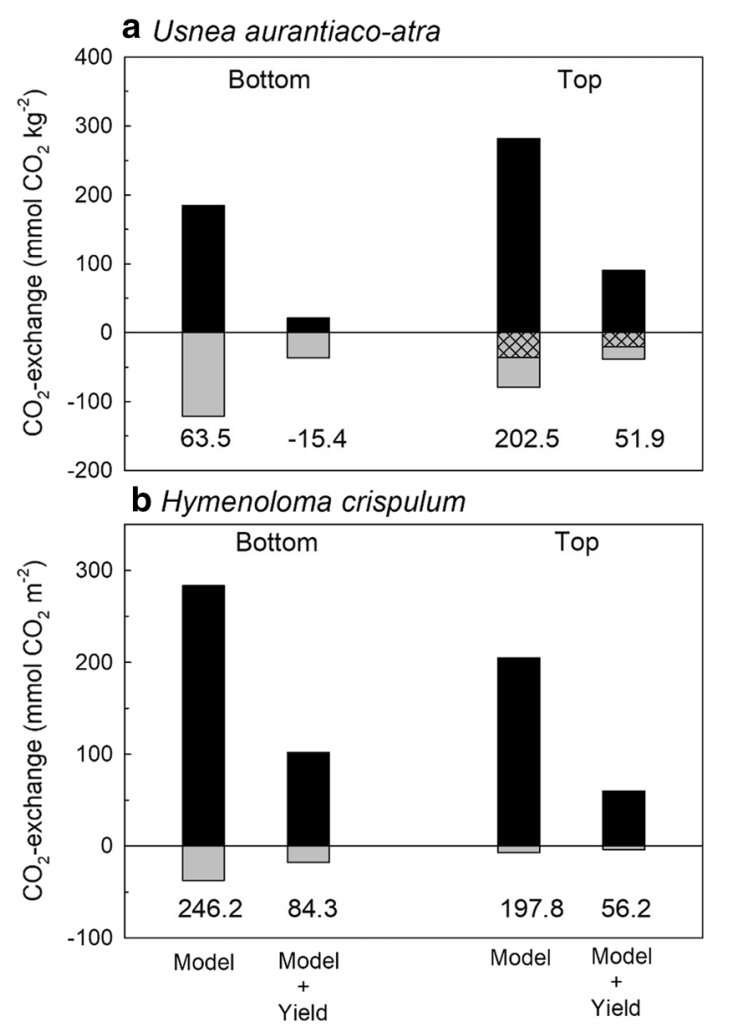

Fig. 8 Modelled carbon balance for Usnea aurantiaco-atra (upper panel) and Hymenoloma crispulum (lower panel) at Bottom sites, left-hand bar pair, and Top sites, right-hand bar pair. Bar fills are black square carbon uptake, grey square carbon loss and, in the case of $U$. aurantiaco-atra, Top site, the hatched part of the carbon loss box with small square represents the contribution from the warming event (JD 33.5 to JD 34.5). The inset numbers below each bar are the Net Carbon Gain. Note: the Y axes of the two graphs have different scales, Upper; $U$. aurantiaco-atra mmol $\mathrm{CO}_{2} \mathrm{~kg}^{-1}$, and Lower, $H$. crispulum, mmol $\mathrm{CO}_{2} \mathrm{~m}^{-2}$ Model indicates that all data were used regardless of whether active or not, Model + Yield indicates that the values from Model have been multiplied by $\mathrm{Y}_{\text {(II) }} / 0.6$ which corrects for occurrence of activity and also effect on photosynthetic rate i.e. a $\mathrm{Y}_{\text {(II) }}$ of 0.6 would give $100 \%$ of photosynthetic rate from Model

aurantiaco-atra temperature was much higher, up to $25.25^{\circ} \mathrm{C}$, and it returned to normal levels at JD $34.8\left(19^{00}\right.$, 3rd February). During this period the lichen was active (positive yield) and the relative humidity close to $100 \%$. The start of the warming event followed a snowfall (10.3 mm rain equivalent) that activated thalli at all sites, ended a 5-day dry period and encased the lichen in an ice-house with a transparent roof. The Pn of $U$. aurantiaco-atra within the ice-house was modelled (NLREG) and showed that in the initial phase Pn were lower than when under normal ambient temperatures (Fig. 9) and were also variable. The start of the warming coincided with the increase in PPFD on JD 33 and, at the highest temperature recorded, $25.25^{\circ} \mathrm{C}$, there was positive $\mathrm{Pn}\left(0.3368 \mu \mathrm{mol} \mathrm{m} \mathrm{m}^{-2} \mathrm{~s}^{-1}\right)$ with PPFD of $882 \mu \mathrm{mol} \mathrm{m}{ }^{-2} \mathrm{~s}^{-1}$. However, the high temperatures enhanced Rd so that on another occasion at $21.35^{\circ} \mathrm{C}$, Pn was

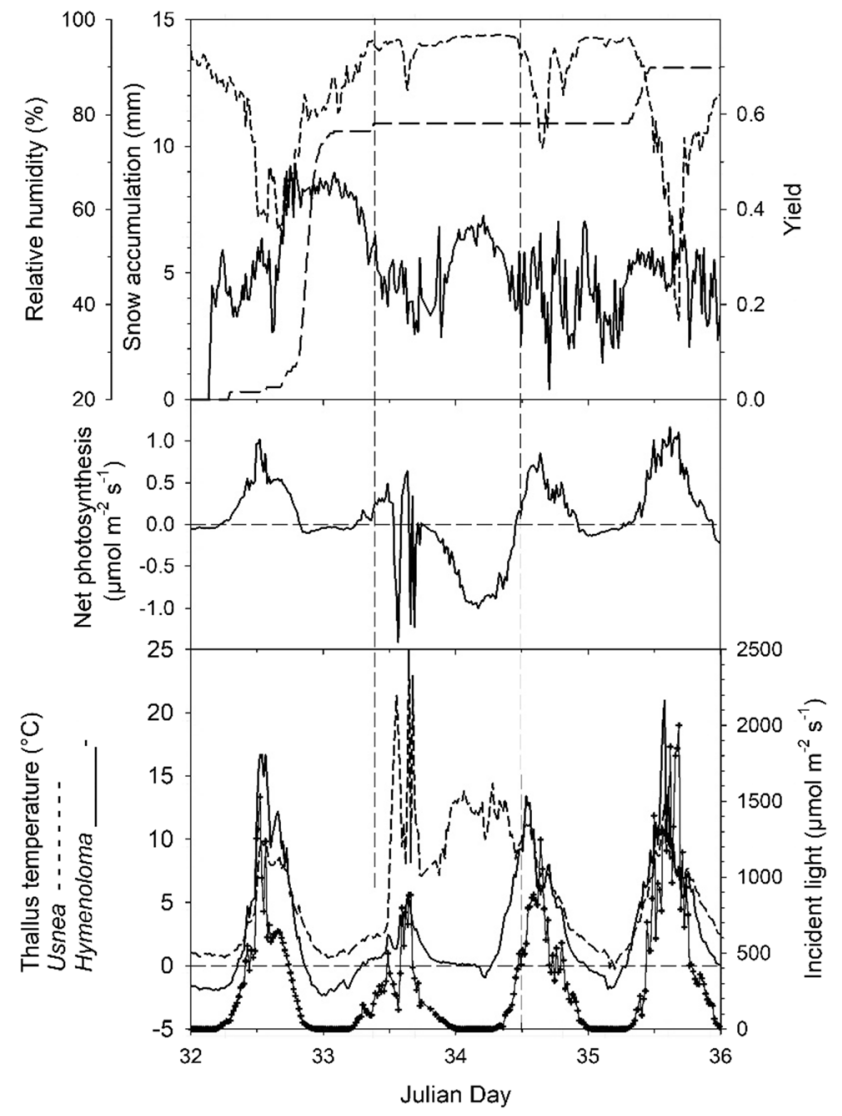

Fig. 9 Warming event during the period JD 32 to 36 at Top site. Upper panel: yield - solid black line, air relative humidity-shortdashed line (\%), snow accumulation - long-dashed line (mm, from Juan Carlos I meteorological station. Middle panel: net photosynthetic rate $\left(\mu \mathrm{mol} \mathrm{CO}_{2} \mathrm{~m}^{-2} \mathrm{~s}^{-1}\right)$ of Usnea obtained from NLREG model - black line, horizontal dashed line indicates zero Pn. Lower Panel: Thallus temperature $\left({ }^{\circ} \mathrm{C}\right)$ - Hymenoloma crispulum, middle solid black line, Usnea aurantiaco-atra, Upper dashed line; incident light (PPFD, $\mu \mathrm{mol} \mathrm{m} \mathrm{m}^{-2} \mathrm{~s}^{-1}$ ) —lower line with crosses $(-+-$ ). In all three panels the vertical dashed lines mark the start and end of the event (JD 33.4 to 34.5 )

negative $\left(-0.7989 \mu \mathrm{mol} \mathrm{m} \mathrm{m}^{-2} \mathrm{~s}^{-1}\right)$ because PPFD was much lower, $220 \mu \mathrm{mol} \mathrm{m} \mathrm{m}^{-2} \mathrm{~s}^{-1}$. Modelled net carbon gain during positive Pn during the event totalled $4.4 \mathrm{mmol} \mathrm{CO}_{2} \mathrm{~kg}^{-1}$ however, overnight, the temperature remained warm, around $11^{\circ} \mathrm{C}$, and this produced a large carbon loss of $24.6 \mathrm{mmol} \mathrm{CO}_{2}$ $\mathrm{kg}^{-1}$ (Fig. 9). Overall, during the event there was a total net carbon loss of $20.2 \mathrm{mmol} \mathrm{CO}_{2} \mathrm{~kg}^{-1}$.

\section{Discussion}

Pintado et al. (2001) tried to explain the decline in species number with increasing altitude at Mt. Reina Sofia, Livingston Island, maritime Antarctica. Several suggestions exist in the literature with the most common being change in nutrient availability from coast to inland, and the decline 
in temperature with increase in altitude. Pintado et al. (2001) used microclimatic data loggers and were able to compare environmental conditions such as thallus temperature and incident light with change in biodiversity. While not definitive, they suggested that the decline in temperature with increase in altitude, around $0.9 \mathrm{~K}$ per $100 \mathrm{~m}$, was very important. Certainly, the distribution of higher plants on Livingston Island shows a strong relationship to altitude and they do not occur above an altitude of $147 \mathrm{~m}$ altitude despite being abundant at low elevations (Vera 2011). Vera (2011) suggested that temperature was important and there is evidence of increased expansion by higher plants as temperatures have risen (Fowbert and Smith 1994). However, higher plants are homoiohydric and maintain a relatively constant water content whereas lichens and mosses are poikilohydric and their water content tends to equilibrium with the environment i.e. they dry out and become dormant when the weather is dry (Kappen 2000). It is possible, therefore, that some change in water availability and consequent changes in activity might also be a driver for diversity change. LagunaDefior et al. (2016) also found a lapse rate of around $0.9 \mathrm{~K}$ $100 \mathrm{~m}^{-1}$ for Mt. Reina Sofia but they also report that VPD (vapour pressure deficit) is around six times greater at the Bottom Site and that dryness could be the major driver of $U$. aurantiaco-atra performance. Here we extend the investigations further by not only using environment monitoring systems, dataloggers, but also chlorophyll fluorometers that indicate when the thalli were active. Knowledge about activity is very important because lichens and mosses are only active when hydrated, prima facie one would expect water status to be an important control on lichen and bryophyte productivity and, through this, diversity.

First, we should check whether we find similar differences in thallus temperature found by previous studies (Pintado et al. 2001; Laguna-Defior et al. 2016) and, in particular, whether they still occur at the times that $H$. crispulum and $U$. aurantiaco-atra are active. Calculating the mean temperatures for all our data for the two species at Top and Bottom sites without considering whether they are active or not, the lapse rates are 1.15 and $0.33{ }^{\circ} \mathrm{C} 100 \mathrm{~m}^{-1}$ for $H$. crispulum and $U$. aurantiaco-atra. Lapse rates were always lower in the light due to the impact of incident radiation and this was particularly true for $U$. aurantiaco-atra $\left(0.27{ }^{\circ} \mathrm{C}\right.$ $\left.100 \mathrm{~m}^{-1}\right)$. Overall, the data confirm that our lapse rates, at least in the dark, are similar to those of Pintado et al. (2001) and Laguna-Defior et al. (2016), at least for H. crispulum, with $U$. aurantiaco-atra having lower rates.

Second, it is important to see if any other important changes occur with increase in altitude, particularly, those affecting water relations. Length of activity is linked to species numbers across Antarctica (Green et al. 2011b), and the activity patterns we found do indeed suggest that there are differences but that these may be complex rather than simple
(Fig. 4). Two patterns are present, one in which activity, as indicated by the $\mathrm{Y}_{(\mathrm{II})}$ is continuous, and this pattern occurs for $U$. aurantiaco-atra Top site, and H. crispulum Middle and Bottom site. The second pattern in which periods of inactivity, i.e. desiccation, occur are $U$. aurantiaco-atra Middle and Bottom, H. crispulum Top. It is immediately clear that the two species are almost opposites in terms of the activity pattern, when one is continuously active the other is occasionally dormant. Morphology is a possible driver as $H$. crispulum, like many bryophytes, has a high, water storage capacity driven by its cushion morphology ( 400\%, unpublished data). Usnea aurantiaco-atra, like most fruticose lichens, has a lower water storage capacity, WCmax of 158\% (Laguna-Defior et al. 2016) and can often show depressed photosynthetic rates at high thallus water contents, the optimal WC being 70\% (Green and Lange 1995; Laguna-Defior et al. 2016). Water storage differences, therefore, may contribute to the continuous activity with $H$. crispulum showing few signs of desiccation, especially at Bottom and Middle sites, while U. aurantiaco-atra shows the opposite situation with obvious signs of desiccation (low yields), especially at lower sites (Fig. 6).

There also appears to be the possibility that differences in water sources may be playing a role. Looking at change in total activity (\%) with altitude (Table 3 ) both species had relatively similar values at the Bottom and Middle sites, $H$. crispulum having higher activities, but differ greatly at the Top site. In comparison with the Middle site, $H$. crispulum at the Top site showed a sharp decline in activity, $70.9 \%$ to $59.0 \%$ (mean of all measurements), whilst $U$. aurantiacoatra shows a large increase, $54.4 \%$ to $82.9 \%$, a difference between the two species of around $23 \%$. In the light, $U$. aurantiaco-atra is $31.2 \%$ more active at the Top site versus the Bottom site, whereas $H$. crispulum is $20.1 \%$ less active at the Top site. In the dark, U. aurantiaco-atra is $24.2 \%$ more active at the Top, whereas $H$. crispulum shows almost no difference between the two sites. The very high activity for $U$. aurantiaco-atra at the Top site indicates that a water source is available for U. aurantiaco-atra that is not, or is less, available to H. crispulum, and does not exist to the same extent at the two lower sites. Figure $2 b$ shows a common feature of Mt Reina Sofia, a cloud cap covering the summit. The bushy form of U. aurantiaco-atra, together with its more exposed situation, means that it is apparently highly effective at capturing water from the cloud droplets whilst $H$. crispulum, close to the surface is ineffective. In contrast, the small differences between activity in the light and dark for $H$. crispulum at the Bottom and Middle site strongly suggests that this species is benefitting from water sourced from melting snow on the rock and, also, by its ability, with its cushion morphology, to store water. At the Top site this source is not so available and the H. crispulum actually shows dormant periods that do not occur at the lower 
sites or for U. aurantiaco-atra at the Top site (Fig. 4). The higher air relative humidity and consequential lower VPD (Laguna-Defoir et al. 2016) at the Top site also slows desiccation which, in combination with the better cloud water capture, means that $U$. aurantiaco-atra remains, in contrast to $H$. crispulum, active for almost the whole time. However, at the Bottom site, with no snow melt or cloud droplets available to it, activity by $U$. aurantiaco-atra is confined to periods of high relative humidity ie: when desiccation pressures are low (Figs. 4, 6, ESM 1).

The ETR response to light also gives information on other possible limiters of activity. At any selected light value, the boundary line indicates the maximal ETR and yield, and any data points lying below this line at the same light level indicate that another factor is limiting (Fig. 6). The most probable additional limiter is desiccation leading to lower thallus water contents and lower yield. This seems to be common for $U$. aurantiaco-atra at all sites but much less so for $H$. crispulum. The latter species shows almost no other limitation at Middle site. It is probable that this, again, reflects the better water relations for the moss morphology and this is supported by the high and continuous yield values at this site (Fig. 4). The totals for ETR also show site differences (Table 4). Hymenoloma crispulum has its highest ETR gain at Middle site, about 35\% less at the Top site and 21\% less at the bottom site. In contrast, U. aurantiaco-atra has similar ETR gain at Top and Middle sites but considerably less, only $17 \%$ of the other sites, at the Bottom site. This depression was probably the consequence of higher desiccation rates and lack of major water storage buffering for the fruticose lichen. Bottom site is also the warmest site, the exact opposite of expectation if temperature decline is the main driver.

The information from ETR and activity is further supported by the results from modelling $\mathrm{CO}_{2}$ exchange with the two species again showing different patterns. Hymenoloma crispulum had higher predicted net carbon gain at the lower site, about 50\% higher than Top site, whilst $U$. aurantiacoatra had net carbon loss at the lower site, $-15.4 \mathrm{mmol} \mathrm{CO}_{2}$ $\mathrm{kg}^{-1}$, compared to a gain at Top site, $51.9 \mathrm{mmol} \mathrm{CO} \mathrm{kg}^{-1}$ (Fig. 8). For both species the net carbon gain appears to be most influenced by differences in carbon uptake which is about $70 \%$ higher at Bottom site for $\mathrm{H}$. crispulum whilst, for $U$. aurantiaco-atra, the reverse situation occurs with carbon uptake at Bottom site being only $24 \%$ of that at Top site (Fig. 8). Carbon loss rates are low for $\mathrm{H}$. crispulum being 3.68 and $17.71 \mathrm{mmol} \mathrm{CO}_{2} \mathrm{~m}^{-2}$ (5.8 and $14.6 \%$ of total carbon exchange) at Top and Bottom sites. Carbon loss rates which are nearly identical at both sites for $U$. aurantiacoatra, 38.2 and $36.6 \mathrm{mmol} \mathrm{CO}_{2} \mathrm{~kg}^{-1}$, Top and Bottom, but are a much higher proportion of total carbon exchange, 29.8 and $63.3 \%$. The results do not support temperature as the main driver but, rather, that water relations are dominant. The fruticose morphology of $U$. aurantiaco-atra seems to make it more sensitive to drying pressures than the clump structure of $\mathrm{H}$. crispulum. The results also support he suggestion by Laguna-Defior et al. (2016) that the continental distribution of $U$. aurantiaco-atra might be driven by drying pressures.

There are other signs of stress in the chlorophyll fluorescence yield data for both $U$. aurantiaco-atra and $H$. crispulum. Yields are almost stable across all 3 sites for both species (Table 2) but values are not close to the expected maximal values commonly seen especially with higher plants of around 0.8. Usnea aurantiaco-atra is around 0.30 and $H$. crispulum around 0.39 . There is also little change in yield with incident PPFD as shown by the linear response of ETR to PPFD in Fig. 6. Normally, yield is expected to decline as PPFD rises so that the response of ETR to light response is non-linear and tends to a saturation value at high light (Schreiber et al. 1995). It is often suggested, and is true for some plant groups, that ETR can be a suitable proxy for photosynthetic rates $\left(\mathrm{CO}_{2}\right.$ exchange). This is certainly not true for these two species as the ETR response to light is linear, whilst the response of net photosynthesis is the normal saturation curve (Fig. 7). The linear response of ETR to light has been previously reported from studies on Antarctic cryptogams (Pannewitz et al. 2003a; Casanova-Katny et al. 2019). The stability of the yield across a large range of lights levels, up to full sunlight, strongly suggests strong downregulation of photochemistry possibly because of the occasional coincidence of activity with moderate to high PPFD at low temperatures and due to involvement of components of the xanthophyll cycle. This situation is known from evergreen plants (Adams et al. 1994, 2004; Verhoeven 2014). Such downregulation will also limit photosynthetic processes but does not explain differences with altitude because the mean yields differ very little between sites.

There are other factors that might also influence growth and competition through effects on the carbon balance. There was little difference in optimal temperature for Pn for H. crispulum indicating a low to no adaptation to temperature differences between sites (Fig. 7). Published results for $U$. aurantiaco-atra show it to have a similar optimal temperature for Pn to that found here for H. crispulum (Schroeter 1997). There was, however, a marked difference in Pn and Pg (area basis) between $H$. crispulum at the Top and Bottom sites for all temperatures from $-1.5^{\circ} \mathrm{C}$ to $25^{\circ} \mathrm{C}$. A similar difference is reported for $U$. aurantiaco-atra (Valladares and Sancho 2000) but this would be partially offset by the longer activity periods at the Top site. It is also important to consider other changes in environmental conditions with altitude. The fluorescence system allows one to see the environmental conditions when the species are active both in the light and the dark. Almost all activity occurs below the optimal temperature for Pn (Fig. 5) so that the optimum is probably better regarded as an upper limit for Pn to occur in the field and this helps to protect the photosynthetic system 
from the combination of high light and low Pn at higher temperatures. There is the possibility that being so active in the dark would lead to substantial carbon losses for $U$. aurantiaco-atra but the modelling of Pn for the warming event shows that $\mathrm{Rd}$ is only a small proportion of the carbon gain in the light probably simply because of the low temperatures limiting Rd (Fig. 8).

An unexpected result was capturing the ice-house phenomenon for $U$. aurantiaco-atra at the Top site (Fig. 9). This phenomenon was reported by Lange (1972) from Cape Hallett. Lange demonstrated that temperatures within the ice-house were up to $20{ }^{\circ} \mathrm{C}$ warmer than the ambient temperatures. The latter were around $-20{ }^{\circ} \mathrm{C}$ so that the situation within the ice-house was expected to be very positive for the lichens and allow carbon gain to occur which would normally not happen. The situation at the Top site is different, ambient temperatures were around $3{ }^{\circ} \mathrm{C}$ and, because the warming was very similar to that found by Lange $\left(+20^{\circ} \mathrm{C}\right)$, temperatures within the ice-house were much higher than the optimum for Pn and there was actually only low carbon gain. In fact, the high temperatures through the night meant that there was a severe net carbon loss. The situation demonstrates that the commonly accepted view that such a situation, a protected warm environment, is positive must be revised and the local conditions taken into account. Snow is known to have other negative effects in Antarctica, At Livingston Island long-lasting snow cover can result in lichen thalli dying due to decreased carbon gain (Sancho et al. 2017). At higher latitudes, in Ross Sea region, snow cover can insulate the lichens so that they remain cold for much longer until the melt occurs (Pannewitz et al. 2003b).

Overall, there are many differences in water relations and, at the lower sites, these favour lichens and mosses deriving water from snow melt and with good water storage potential, whilst at the Top site $U$. aurantiaco-atra is favoured as it can capture cloud water. The results from the photosynthetic modelling which take into account both duration and level of activity show that the major effects are on carbon uptake with desiccation playing a key role. This situation could cause large changes in competitiveness and this could well drive the diversity differences found. This may also explain the abundance at Top site of the fruticose lichen, Himantormia lugubris., which shares the community with $U$. aurantiaco-atra and shows even lower Pn values (Sancho et al. 2020).However, and it is an important however, the role of nutrients is likely to also be crucial as this would influence overall growth (Valladares and Sancho 2000). This possibility is supported by the distribution of lichens at Cape Hallett which shows a clear influence of high ammonia inputs (Crittenden et al. 2015) so that there is a distinct change in lichen flora from a high nutrient flora at lower altitudes to a low nutrient flora at the higher sites (Green et al. 2015).

\section{Conclusions}

Mean temperature did decline with altitude and, because all photosynthetic activity is at sub-optimal temperatures, an increase in temperature should always drive increased net carbon gain. Modelling of photosynthesis, activity and chlorophyll fluorescence all suggest that water relations may play a major role in cryptogam performance in Antarctica which is not unexpected because the lichens and mosses are poikilohydric. Differences in water sources at the three sites play a role with the moss, $H$. crispulum, benefitting from melt water situation does better at the lower sites. Usnea aurantiaco-atra, being fruticose and bushy in morphology profits from water droplet capture from clouds at the top site. However, the most important driver seems to be drying which is much higher at the Bottom site and which has a strong impact on the fruticose $U$. aurantiaco-atra producing net carbon loss but less on $H$. crispulum which is probably buffered by better water storage through its clump structure. Both species appear to be under stress probably resulting from high light levels occurring at low temperatures. This is indicated by down-regulation of the photosynthetic yield which remains constant regardless of incident light. The warming event shows once again the potential negative effects of snow cover producing a major increase in carbon loss for $U$. aurantiaco-atra despite lasting only one day, something that is known from studies on lichen growth rates nearby (Sancho et al. 2017). The reported alteration in lichen flora with altitude is probably the result of a combination of changes in activity and water source plus, one suspects, a strong influence from nutrients at lower altitudes and occasional negative effects of long-lasting snow cover. Taken together, it seems that the use of an altitudinal gradient as a proxy for temperature change across the continent has complications that means the method can only be used with considerable caution.

Supplementary Information The online version contains supplementary material available at https://doi.org/10.1007/s00300-021-02939-9.

Acknowledgements BS gratefully acknowledges financial support by Deutsche Forschungs-Gemeinschaft (DFG SCHR 473/4-7) and by Spanish MCI (ANTEX, REN2003-07366-C02-01). LGS and AP were supported by Spanish MCI (PID2019-105469RB-C21), we also thank the staff of the Spanish Antarctic Station, Juan Carlos I, for their support. TGAG was supported by Ramon y Cajal Fellowship at Biología Vegetal II, Farmacia, Universidad Complutense, Madrid, Spain, and by a FRST grant (Understanding, valuing and protecting Antarctica's unique terrestrial ecosystems: predicting biocomplexity in Dry Valley ecosystems) during the writing of this paper. Permits for the research 
came from the Spanish Polar Committee (reference number: CPE-EIA1999B). The constructive comments on this paper by Dr. Helga Bültmann and two other anonymous reviewers are gratefully acknowledged.

Author contributions All authors contributed to the study conception and design. Material preparation, data collection and analysis were performed by TGAG and BS. The first draft of the manuscript was written by TGAG and BS and all authors commented on drafts of the manuscript. All authors read and approved the final manuscript.

Funding Open Access funding provided thanks to the CRUE-CSIC agreement with Springer Nature. BS: Deutsche Forschungs-Gemeinschaft (DFG SCHR 473/ 4-7), Spanish MCI (ANTEX, REN200307366-C02-01). LGS and AP were supported by Spanish MCI (PID2019-105469RB-C21).

Data availability Available from corresponding author on reasonable request.

\section{Declarations}

Conflict of interest All authors declare that they have no competing interest.

Ethical approval Permits obtained from appropriate authorities.

Consent for publication All authors agree.

Dedication This paper is dedicated to Professor Ludger Kappen to recognise not just his immense contribution to our understanding of Antarctic terrestrial vegetation but, also, that he introduced most of the authors to Antarctic research. He has left a massive legacy which underpins much of present understanding of Antarctic terrestrial systems.

Open Access This article is licensed under a Creative Commons Attribution 4.0 International License, which permits use, sharing, adaptation, distribution and reproduction in any medium or format, as long as you give appropriate credit to the original author(s) and the source, provide a link to the Creative Commons licence, and indicate if changes were made. The images or other third party material in this article are included in the article's Creative Commons licence, unless indicated otherwise in a credit line to the material. If material is not included in the article's Creative Commons licence and your intended use is not permitted by statutory regulation or exceeds the permitted use, you will need to obtain permission directly from the copyright holder. To view a copy of this licence, visit http://creativecommons.org/licenses/by/4.0/.

\section{References}

Adams WW, Demmig-Adams B, Verhoeven AS, Barker DH (1994) 'Photoinhibition' during winter stress: involvement of sustained xanthophyll cycle-dependent energy dissipation. Aust J Plant Physiol 22:261-276

Adams WW, Zarter CR, Ebbert V, Demmig-Adams B (2004) Photoprotective strategies of overwintering evergreens. Bioscience 54:41-49

Bokhorst S, Huiskes A, Convey P, Sinclair BJ, Lebouvier M, Van de Vijver B, Wall DH (2011) Microclimate impacts of passive warming methods in Antarctica: implications for climate change studies. Polar Biol 34:1421-1435

Bokhorst S, Huiskes AD, Aerts R, Convey P, Cooper EJ, Dalen L, Erschbamer B, Gudmundsson J, Hofgaard A, Hollister RD, Johnstone J (2013) Variable temperature effects of Open Top Chambers at polar and alpine sites explained by irradiance and snow depth. Glob Chang Biol 19:64-74

Brabyn L, Beard C, Seppelt RD, Rudolph ED, Türk R, Green TGA (2006) Quantified vegetation change over 42 years at Cape Hallett, East Antarctica. Antarct Sci 18:561-572

Breshears DD, Huxman TE, Adams HD, Zou CB, Davison JE (2008) Vegetation synchronously leans upslope as climate warms. PNAS 105:11591-11592

Cannone N, Guglielmin M, Convey P, Worland MR, Longo F (2016) Vascular plant changes in extreme environments: effects of multiple drivers. Clim Change 134:651-665

Casanova-Katny A, Barták M, Gutierrez C (2019) Open top chamber microclimate may limit photosynthetic processes in Antarctic lichen: Case study from King George Island, Antarctica. Czech Polar Rep 9:61-77

Colesie C, Green TGA, Haferkamp I, Büdel B (2014a) Habitat stress initiates changes in composition, $\mathrm{CO}_{2}$ gas exchange and C-allocation as life traits in biological soil crusts. ISME J 8:2104-2115. https://doi.org/10.1038/ismej.2014.47

Colesie C, Green TGA, Türk R, Hogg ID, Sancho LG, Büdel B (2014b) Terrestrial biodiversity along the Ross Sea coastline, Antarctica: lack of a latitudinal gradient and potential limits of bioclimatic modeling. Polar Biol 37:1197-1208

Convey P, Peck LS (2019) Antarctic environmental change and biological responses. Sci Adv 5:eaaz0888. https://doi.org/10.1126/ sciadv.aaz0888

Crittenden PD, Scrimgeour CM, Minnullina G, Sutton MA, Tang YS, Theobald MR (2015) Lichen response to ammonia deposition defines the footprint of a penguin rookery. Biogeochem 122:295-311

Fowbert JA, Smith RIL (1994) Rapid population increases in native vascular plants in the Argentine Islands, Antarctic Peninsula. Arct Alp Res 26:290-296

Genty B, Briantais JM, Baker NR (1989) The relationship between the quantum yield of photosynthetic electron transport and quenching of chlorophyll fluorescence. Biochim Biophys Acta 990:87-92

Golledge NR, Everest JD, Bradwell T, Johnson JS (2010) Lichenometry on Adelaide island, Antarctic peninsula: size-frequency studies, growth rates and snow patches. Geograf Ann A 92:111-124

Green TGA, Lange OL (1995) Photosynthesis in poikilohydric plants: a comparison of lichens and bryophytes. In: Schulze DE, Caldwell MM (eds) Ecophysiology of photosynthesis. Springer-Verlag, Berlin Heidelberg New York, pp 319-342

Green TGA, Büdel B, Meyer A, Zellner H, Lange OL (1997) Temperate rainforest lichens in New Zealand: light response of photosynthesis. NZ J Bot 35:493-504

Green TGA, Schroeter B, Sancho LG (2007) Plants in Antarctica. In: Pugnaire F, Valladares F (eds) Plants in Antarctica. Handbook of functional plant ecology. 2nd edn. Marcel Dekker, New York, pp 495-544

Green TGA, Sancho LG, Pintado A (2011a) Ecophysiology of desiccation/rehydration cycles in mosses and lichens. In: Lüttge U, Beck E, Bartels E (eds) Plant desiccation tolerance. Springer, Berlin Heidelberg, pp 89-120

Green TGA, Sancho LG, Pintado A, Schroeter B (2011b) Functional and spatial pressures on terrestrial vegetation in Antarctica forced by global warming. Polar Biol 34:1643-1656

Green TGA, Sancho LG, Türk R, Seppelt RD, Hogg ID (2011c) High diversity of lichens at $84 \mathrm{~S}$, Queen Maud Mountains, suggests 
preglacial survival of species in the Ross Sea region, Antarctica. Polar Biol 34:1211-1220

Green TGA, Brabyn L, Beard C, Sancho LG (2012) Extremely low lichen growth rates in Taylor Valley, Dry Valleys, continental Antarctica. Polar Biol 35:535-541

Green TGA, Seppelt RD, Brabyn LR, Beard C, Türk R, Lange OL (2015) Flora and vegetation of Cape Hallett and vicinity, northern Victoria Land, Antarctica. Polar Biol 38:1825-1845

Kappen L (2000) Some aspects of the great success of lichens in Antarctica. Antarct Sci 12:314-324

Körner C (2021) Alpine plant life: Functional plant ecology of high mountain ecosystems. Springer-Verlag, Berlin Heidelberg

Laguna-Defior C, Pintado A, Green TGA, Blanquer JM, Sancho LG (2016) Distributional and ecophysiological study on the Antarctic lichens species pair Usnea antarctica/Usnea aurantiaco-atra. Polar Biol 39:1183-1195

Lange OL (1972) Flechten-Pionierpflanzen in Kältewüsten. Umschau 72:650-654

Lévesque E, Svoboda J (1999) Vegetation re-establishment in polar "lichen-kill" landscapes: a case study of the Little Ice Age impact. Polar Res 18:221-228

Levy JS, Fountain AG, Gooseff MN, Barrett JE, Vantreese R, Welch KA, Lyons WB, Nielsen UL, Wall DH (2014) Water track modification of soil ecosystems in the Lake Hoare basin, Taylor Valley, Antarctica. Antarct Sci 26:153-162

Nielsen UN, Wall DH, Adams BJ, Virginia RA, Ball BA, Gooseff MN, McKnight DM (2012) The ecology of pulse events: insights from an extreme climatic event in a polar desert ecosystem. Ecosphere $3: 1-15$

Pannewitz S, Green TGA, Scheidegger C, Schlensog M, Schroeter B (2003a) Activity pattern of the moss Hennediella heimii (Hedw.) Zand. in the Dry Valleys, Southern Victoria Land, Antarctica during the mid-austral summer. Polar Biol 26:545-551

Pannewitz S, Schlensog M, Green TGA, Sancho LG, Schroeter B (2003b) Are lichens active under snow in continental Antarctica? Oecologia 135:30-38

Pannewitz S, Green TGA, Schlensog M, Seppelt R, Sancho LG, Schroeter B (2006) Photosynthetic performance of Xanthoria mawsonii CW Dodge in coastal habitats, Ross Sea region, continental Antarctica. Lichenologist 38:67-81

Peat HJ, Clarke A, Convey P (2007) Diversity and biogeography of the Antarctic flora. J Biogeog 34:132

Pintado A, Sancho LG, Valladares F (2001) The influence of microclimate on the composition of lichen communities along an altitudinal gradient in the maritime Antarctic. Symbiosis 31:69-84

Pontailler JY (1990) A cheap quantum sensor using a gallium arsenide photodiode. Funct Ecol 4:591-596

Raggio J, Pintado A, Vivas M, Sancho LG, Büdel B, Colesie C, Weber B, Schroeter B, Lázaro R, Green TGA (2014) Continuous chlorophyll fluorescence, gas exchange and microclimate monitoring in a natural soil crust habitat in Tabernas badlands, Almería, Spain: progressing towards a model to understand productivity. Biodivers Conserv 23:1809-1826

Robinson SA, King DH, Bramley-Alves J, Waterman MJ, Ashcroft MB, Wasley J, Turnbull JD, Miller RE, Ryan-Colton E, Benny E, Mullany K (2018) Rapid change in East Antarctic terrestrial vegetation in response to regional drying. Nat Clim Change 8:879-884

Sancho LG, Kappen L (1989) Photosynthesis and water relations and the role of anatomy in Umbilicariaceae (lichenes) from Central Spain. Oecologia 81:473-480

Sancho LG, Schulz F, Schroeter B, Kappen L (1999) Bryophyte and lichen flora of South Bay (Livingston Island: South Shetland Islands, Antarctica). Nova Hedwigia 68:301-338

Sancho LG, Pintado A, Navarro F, Ramos M, De Pablo MA, Blanquer JM, Raggio J, Valladares F, Green TGA (2017) Recent warming and cooling in the Antarctic Peninsula region has rapid and large effects on lichen vegetation. Sci Rep 7:1-8

Sancho LG, Pintado A, Green TGA (2019) Antarctic studies show lichens to be excellent biomonitors of climate change. Diversity 11:42. https://doi.org/10.3390/d11030042

Sancho L, De Los RA, Pintado A, Colesie C, Raggio J, Ascaso C, Green TGA (2020) Himantormia lugubris, an Antarctic endemic on the edge of the lichen symbiosis. Symbiosis 82:49-58

Schlensog M, Schroeter B (2001) A new method for the accurate in situ monitoring of chlorophyll a fluorescence in lichens and bryophytes. Lichenologist 33:443-452

Schlensog M, Green TGA, Schroeter B (2013) Life form and water source interact to determine active time and environment in cryptogams: an example from the maritime Antarctic. Oecologia 173:59-72

Schreiber U, Bilger W, Neubauer C (1995) Chlorophyll fluorescence as a nonintrusive indicator for rapid assessment of in vivo photosynthesis. In: Schulze DE, Caldwell MM (eds) Ecophysiology of photosynthesis. Springer-Verlag, Berlin, pp 49-70

Schroeter B (1997) Grundlagen der Stoffproduktion von Kryptogamen unter besonderer Berücksichtigung der Flechten - eine Synopse. Habilitation Thesis, Christian-Albrechts-Universität Kiel

Schroeter B, Green TGA, Kappen L, Seppelt RD (1994) Carbon dioxide exchange at subzero temperatures. Field measurements on Umbilicaria aprina in continental Antarctica. Cryptogamic Bot 4:233-241

Schroeter B, Olech M, Kappen L, Heitland W (1995) Ecophysiological investigations of Usnea antarctica in the maritime Antarctic. I. Annual microclimatic conditions and potential primary production. Antarct Sci 7:251-260

Schroeter B, Green TGA, Pintado A, Türk R, Sancho LG (2017) Summer activity patterns for mosses and lichens in Maritime Antarctica. Antarct Sci 29:517-530

Schwarz AMJ, Green TGA, Seppelt RD (1992) Terrestrial vegetation at Canada Glacier, Southern Victoria Land, Antarctica. Polar Biol 12:397-404

Seppelt RD, Türk R, Green TGA, Moser G, Pannewitz S, Sancho LG, Schroeter B (2010) Lichen and moss communities of Botany Bay, Granite Harbour, Ross Sea, Antarctica. Antarct Sci 22:691-702

Smith RIL (1996) Terrestrial and freshwater biotic components of the western Antarctic Peninsula. In: Hofmann EE, Ross RM, Quetin LB (eds) Foundations for ecological research west of the Antarctic Peninsula, Antarctic Research Series, vol 70. American Geophysical Union, Washington, pp 15-59

Søchting U, Øvstedal DO, Sancho LG (2004) The lichens of Hurd Peninsula, Livingston Island, South Shetland Islands, Antarctica. Bibl Lich 88:607-658

Stevens MI, Hogg ID (2003) Long-term isolation and recent range expansion from glacial refugia revealed for the endemic springtail Gomphiocephalus hodgsoni from Victoria Land, Antarctica. Mol Ecol 12:2357-2369

Torres-Mellado GA, Jana R, Casanova-Katny MA (2011) Antarctic hairgrass expansion in the South Shetland archipelago and Antarctic Peninsula revisited. Polar Biol 34:1679-1688

Valladares F, Sancho LG (2000) The relevance of nutrient availability for lichen productivity in the maritime Antarctic. Bibl Lichenol 75:189-199

Vera ML (2011) Colonization and demographic structure of Deschampsia antarctica and Colobanthus quitensis along an altitudinal gradient on Livingston Island, South Shetland Islands. Antarctica Polar Res 30:7146. https://doi.org/10.3402/polar.v30i0.7146

Verhoeven A (2014) Sustained energy dissipation in winter evergreens. New Phytol 201:57-65

Publisher's Note Springer Nature remains neutral with regard to jurisdictional claims in published maps and institutional affiliations. 